\title{
A review of fibrin and fibrin composites for bone tissue engineering
}

\author{
This article was published in the following Dove Press journal: \\ International Journal of Nanomedicine \\ 12 July 2017 \\ Number of times this article has been viewed
}

\author{
Alireza Noori ${ }^{1}$ \\ Seyed Jamal Ashrafi \\ Roza Vaez-Ghaemi ${ }^{3}$ \\ Ashraf Hatamian-Zaremi ${ }^{4}$ \\ Thomas J Webster ${ }^{5}$ \\ 'Department of Tissue Engineering \\ and Applied Cell Sciences, Faculty of \\ Advanced Technologies in Medicine, \\ Tehran University of Medical Sciences, \\ Tehran, ${ }^{2}$ School of Medicine, Shahroud \\ University of Medical Sciences, \\ Shahroud, Iran; ${ }^{3}$ Department of \\ Chemical and Biological Engineering, \\ Faculty of Biomedical Engineering, \\ The University of British Columbia, \\ Vancouver, BC, Canada; ${ }^{4}$ Faculty of \\ New Sciences and Technologies, \\ University of Tehran, Tehran, Iran; \\ ${ }^{5}$ Department of Chemical Engineering, \\ Northeastern University, Boston, \\ MA, USA
}

Abstract: Tissue engineering has emerged as a new treatment approach for bone repair and regeneration seeking to address limitations associated with current therapies, such as autologous bone grafting. While many bone tissue engineering approaches have traditionally focused on synthetic materials (such as polymers or hydrogels), there has been a lot of excitement surrounding the use of natural materials due to their biologically inspired properties. Fibrin is a natural scaffold formed following tissue injury that initiates hemostasis and provides the initial matrix useful for cell adhesion, migration, proliferation, and differentiation. Fibrin has captured the interest of bone tissue engineers due to its excellent biocompatibility, controllable biodegradability, and ability to deliver cells and biomolecules. Fibrin is particularly appealing because its precursors, fibrinogen, and thrombin, which can be derived from the patient's own blood, enable the fabrication of completely autologous scaffolds. In this article, we highlight the unique properties of fibrin as a scaffolding material to treat bone defects. Moreover, we emphasize its role in bone tissue engineering nanocomposites where approaches further emulate the natural nanostructured features of bone when using fibrin and other nanomaterials. We also review the preparation methods of fibrin glue and then discuss a wide range of fibrin applications in bone tissue engineering. These include the delivery of cells and/or biomolecules to a defect site, distributing cells, and/or growth factors throughout other pre-formed scaffolds and enhancing the physical as well as biological properties of other biomaterials. Thoughts on the future direction of fibrin research for bone tissue engineering are also presented. In the future, the development of fibrin precursors as recombinant proteins will solve problems associated with using multiple or single-donor fibrin glue, and the combination of nanomaterials that allow for the incorporation of biomolecules with fibrin will significantly improve the efficacy of fibrin for numerous bone tissue engineering applications.

Keywords: fibrin, fibrinogen, injectable hydrogel, fibrin preparation, fibrin beads, fibrin coating, nanofibrous scaffold, bone repair

\section{Introduction}

There are over 200 bones of different shapes, sizes, and functions in the human body. They provide the weight-bearing structure for the body and play several important roles such as protection of the most vital organs, movement and locomotion of the body, production of blood cells, and acting as a storehouse for growth factors and minerals. ${ }^{1}$ Therefore, loss of this multifunctional tissue adversely affects the patient's quality of life and represents a burden for the health care system. Fortunately, bone exhibits unique regenerative capacity and can heal without structural or functional impairment. However, if the defect size is greater than the healing capacity of osteogenic tissues, the site will not regenerate spontaneously. Furthermore, diseased bones are incapable of complete healing. In this situation, orthopedic surgeons have different biomaterial
Correspondence: Seyed Jamal Ashrafi Shahroud University of Medical Sciences and Health Services, School of Medicine, 7 Tir Square, Shahroud 36I4773955, Iran Email ashrafi.shmu@gmail.com

Thomas J Webster

Department of Chemical Engineering, 313 Snell Engineering Center, 360 Huntington Avenue, Northeastern University, Boston, MA 02115, USA

Email th.webster@neu.edu 
possibilities: autogenous bone grafting, allogenic bone grafting, or the use of synthetic biomaterials.

Autogenous bone grafts that involve harvesting the bone from one site (usually from the iliac crest) of the patient and transplanting it into a damaged area of the same patient comprise $~ 58 \%$ of bone substitutes and remain the gold standard for the reconstruction of small bone defects. ${ }^{2}$ They possess osteoconductive, osteoinductive, and osteogenic characteristics due to the presence of bone chips, osteogenic cells, and growth factors, respectively. ${ }^{3}$ Nevertheless, their use is associated with disadvantages including donor site morbidity, limited graft supply, bleeding, chronic pain, infections, and poor cosmetic outcomes. ${ }^{3}$

The allograft, which involves transplanting donor bone tissue, often from a cadaver, constitutes $\sim 34 \%$ of the bone substitutes. ${ }^{2}$ Allogeneic bone grafts are not associated with donor site morbidity and are available in various forms and sizes. However, several drawbacks are associated with allografts: risk of transmission of infectious diseases, possibility of immunological rejection, and loss of biological and mechanical properties due to graft sterilization. Moreover, the demand for allograft tissue far exceeds the available supply. ${ }^{3-5}$

Bioinert materials such as alumina, stainless steel, and poly(methyl methacrylate) (PMMA) have been used in a wide range of bone surgeries. The considerable advantages of these implants over biological grafts are their availability and reproducibility. However, these biomaterials do not integrate well with the host bone and are encapsulated by fibrous tissue after implantation in the body. Production of wear debris and a high mismatch in stiffness between load-bearing implants and the adjacent bone are additional limiting factors. ${ }^{6,7}$

Tissue engineering has emerged as a new therapeutic approach for bone repair and regeneration, seeking to overcome such potential problems related to the aforementioned approaches. The optimal tissue-engineered construct relies on three essential components: a suitable cell source, growth and differentiation factors, and an appropriate scaffold to support cell-based regeneration of tissue. So, scaffolds play a pivotal role in bone tissue engineering and the selection of an appropriate biomaterial is crucial. Scaffold materials must be biocompatible, biodegradable, facilitate cell penetration and bone ingrowth, provide biomechanical support until the cells regenerate bone, be inexpensive, readily available and easy to produce and handle. ${ }^{8,9}$ To fulfill these requirements, numerous biomaterials have been widely tested with varying success. Details of their advantages and disadvantages are found in many other comprehensive reviews. ${ }^{10-12}$

Fibrin possesses remarkable advantages over other biomaterials, which makes it an ideal candidate for bone tissue engineering applications. It is nature's nano-scaffold following tissue injury to initiate hemostasis and provide a temporary structure that facilitates cellular activities and also deposition of a new extracellular matrix (ECM). ${ }^{13,14}$ Fibrin gel precursors, fibrinogen and thrombin, can be derived from a patient's own blood, which enables the fabrication of completely autologous and inexpensive scaffolds. Moreover, owing to its multiple interaction sites for cells and other proteins, fibrin acts as a bioactive matrix and is suitable for cell and biomolecule delivery systems. ${ }^{13}$ In addition, the structural properties of fibrin substrates can be easily controlled by changes in fibrinogen and/or thrombin concentrations in the precursor solutions. ${ }^{15}$ Furthermore, fibrin can be injected as a liquid and it solidifies thereafter in situ; thus, it can fill bone gaps with any shape or geometry. However, because of the rapid degradation and weak mechanical properties of fibrin, many investigators use fibrin in combination with other materials to overcome such limitations. Nanomaterials have become a popular material to use with fibrin in order to promote bioactivity of fibrin and to further emulate the natural nanostructured features of bone itself.

\section{Difficulties involved in assessing the literature}

Despite the ever-increasing volume of publications regarding the use of fibrin in bone tissue engineering, the usefulness of fibrin remains debatable. Much of the contradiction among the literature arises from using a variety of different fibrin glues (Table 1). Fibrin glue can be prepared either from pooled plasma, for example, commercially available fibrin sealants, or from single-donor plasma. Isolation techniques (eg, cryoprecipitation and ethanol precipitation), batch to batch variability, and composition (eg, concentration of thrombin, fibrinogen, factor XIII, and antifibrolytics) lead to different mechanical and biological properties of the generated clots. ${ }^{16,17}$ For example, Dickneite et al showed clear differences in hemostatic and clot strength properties of 12 commercially available fibrin sealants. ${ }^{17}$ Furthermore, differences in component origin may change the biochemistry of the clot, like interspecies or pooled and single donor. ${ }^{18,19}$ Variations in experimental design, implantation site, and animal models as well as fibrinogen and thrombin concentrations are other parameters that make direct comparison of the research findings difficult. Moreover, to achieve the desired biological and/or physical properties for bone tissue engineering applications, fibrin must be reinforced, and there is a board range of nano- and other materials such as autogenous bone grafts, ${ }^{20,21}$ allogenic bone grafts,,${ }^{22,23}$ xenogeneic bone grafts,,${ }^{24}$ metals, ${ }^{25-27}$ ceramics, ${ }^{28-30}$ 
Table I Diversity in fibrin sealants and experimental design seen in the literature

\begin{tabular}{|c|c|c|c|c|c|c|c|}
\hline $\begin{array}{l}\text { Trade } \\
\text { name }\end{array}$ & $\begin{array}{l}\text { Fibrinogen } \\
(\mathrm{mg} / \mathrm{mL})\end{array}$ & $\begin{array}{l}\text { Thrombin } \\
\text { (IU/mL) }\end{array}$ & $\begin{array}{l}\text { Factor XIII } \\
(\mathrm{U} / \mathrm{mL})\end{array}$ & $\begin{array}{l}\text { Aprotinin } \\
(\mathrm{KIU} / \mathrm{mL})\end{array}$ & Adjacent agent & $\begin{array}{l}\text { Implantation } \\
\text { site }\end{array}$ & References \\
\hline Biocol $^{\circledR}$ & 127 & 558 & 11 & 3,000 & $\begin{array}{l}\text { Calcium carbonate } \\
\text { granules and TGF- } \beta\end{array}$ & Parietal (rabbit) & 145 \\
\hline Quixil $^{\circledR}$ & $60-100$ & 1,000 & None & $\begin{array}{l}\text { Transexamic } \\
\text { acid }\end{array}$ & Autologous bone graft & $\begin{array}{l}\text { Alveolar bone } \\
\text { (human) }\end{array}$ & 125 \\
\hline Bolheal $^{\circledR}$ & 80 & 250 & 75 & 1,000 & $\beta$-TCP and BMSc & Subcutaneous (rat) & 197 \\
\hline Beriplast $^{\circledast}$ & $65-115$ & $400-600$ & $40-80$ & $\mathrm{I}, 000$ & $\begin{array}{l}\text { Allogenic periosteal cell } \\
\text { and PLGA }\end{array}$ & Ulna (rabbit) & 104 \\
\hline Tisseel $^{\circledR}$ & $75-115$ & 500 & $10-50$ & 3,000 & MSCs/HA-coated titanium & Tibia (sheep) & 114 \\
\hline Tisseel & $75-115$ & 500 & $10-50$ & 3,000 & $\begin{array}{l}\text { Biphasic calcium } \\
\text { phosphate ceramic }\end{array}$ & $\begin{array}{l}\text { Different locations } \\
\text { (human) }\end{array}$ & 140 \\
\hline Tisseel & $75-115$ & 500 & $10-50$ & 3,000 & $\begin{array}{l}\text { Biphasic calcium } \\
\text { phosphate ceramic }\end{array}$ & Femur (rabbit) & 138 \\
\hline Tisseel & $75-115$ & 500 & $10-50$ & 3,000 & MDSCs & Calvarium (mouse) & $17 \mid$ \\
\hline Greenplast $^{\circledR}$ & 100 & 500 & 66 & 1,100 & $\begin{array}{l}\text { Apatite-coated PLGA/HA } \\
\text { particulates and BMP-2 }\end{array}$ & Calvarium (rat) & 169 \\
\hline Bolsea $^{\circledR}$ & $\begin{array}{l}\text { 50-75 (porcine } \\
\text { fibrinogen) }\end{array}$ & 400 & $10-70$ & & $\begin{array}{l}\text { Gelatin/HA nanoparticles } \\
\text { and (BMP-2) }\end{array}$ & $\begin{array}{l}\text { Radial diaphysis } \\
\text { (rabbit) }\end{array}$ & 36 \\
\hline Sigma & 200 & 100 & & & HA nanoparticles/BMP-2 & Calvarium (mouse) & 186 \\
\hline \multirow[t]{4}{*}{ Calbiochem } & 20 & 2.5 & & & $\begin{array}{l}\text { Apatite-coated PLGA } \\
\text { microspheres }\end{array}$ & Calvarium (rat) & 198 \\
\hline & $\begin{array}{l}\text { Single-donor } \\
\text { human }\end{array}$ & $\begin{array}{l}\text { Bovine thrombin } \\
\left(\text { Merck }^{\circledR}\right)\end{array}$ & & & HA and HABGS & $\begin{array}{l}\text { Intramuscular } \\
\text { (mouse) }\end{array}$ & 19 \\
\hline & Autologous & Autologous & & $\begin{array}{l}\text { Tranexamic } \\
\text { acid }\end{array}$ & Autogenous bone grafts & $\begin{array}{l}\text { Maxillary sinus } \\
\text { (dog) }\end{array}$ & 128 \\
\hline & $\begin{array}{l}\text { Single-donor } \\
\text { (rat origin) }\end{array}$ & $\begin{array}{l}\text { Single-donor } \\
\text { (rat origin) }\end{array}$ & & $\begin{array}{l}\text { Tranexamic } \\
\text { acid }\end{array}$ & $\begin{array}{l}\text { Osteogenic cells and } \\
\text { BMP-2 }\end{array}$ & $\begin{array}{l}\text { Subcutaneous of } \\
\text { dorsum (mouse) }\end{array}$ & 199 \\
\hline
\end{tabular}

Abbreviations: TGF- $\beta$, transforming growth factor- $\beta$; $\beta$-TCP, $\beta$-tricalcium phosphate; PLGA, poly(lactide-co-glycolide); HA, hydroxyapatite; MDSC, muscle-derived stem cells; BMSC, bone marrow-derived stromal cell; MSC, mesenchymal stem cell; BMP-2, bone morphogenetic protein 2; HABGS, Calcium phosphate calcium silicate system.

polymers, ${ }^{31-33}$ and composites. ${ }^{34-36}$ Biological components including (but not limiting to) mesenchymal stem cells (MSCs) derived from various tissues such as bone marrow, ${ }^{18}$ adipose tissue, ${ }^{37}$ umbilical cord,${ }^{32}$ muscle, ${ }^{38}$ skin,,${ }^{39}$ tooth,${ }^{40}$ and osteoblasts from different regions ${ }^{41-43}$ and also several biomolecules and growth factors like bone morphogenetic protein (BMP) ${ }^{37}$ basic fibroblast growth factor (bFGF), ${ }^{41}$ and vascular endothelial growth factor (VEGF) ${ }^{44}$ can be used in combination with fibrin. Different properties of these adjacent materials led to different results both in vitro and in vivo. ${ }^{45}$

However, all fibrin that is used in the literature is the same in that it is a natural biopolymer with unique physical and biological properties. These qualities have attracted much attention for the use of fibrin glue in bone tissue engineering. With these conflicting results in mind, the following sections explore the role of fibrin in these studies (Table 1).

\section{Composition, structure, and properties of fibrin Composition and structure of fibrin}

Fibrin is a natural biopolymer formed in the last step of the clotting cascade by the action of thrombin on fibrinogen. ${ }^{46}$
Fibrinogen is a large, complex, fibrous glycoprotein essential to many biological processes such as hemostasis, wound healing, inflammation, angiogenesis, and so on ${ }^{47} \mathrm{It}$ is composed of two sets of three polypeptide chains ( $\mathrm{A} \alpha, \mathrm{B} \beta$, and $\gamma$ ), including the fibrinopeptides $\mathrm{A}$ and $\mathrm{B}$, which are joined together by 29 disulfide bonds within the E domain. The $\alpha$ and $\gamma$ chains are linked to the same chains of the opposite subunit by one and two interchain disulfide bond(s), respectively. The two $\beta$ chains are not directly linked to each other: the $\beta$ chain of one subunit is linked to the $\alpha$ chain of the other subunit via a disulfide bond, while an additional disulfide bond connects the second $\beta$ chain to the $\gamma$ chain of the opposite subunit (Figure 1). ${ }^{48}$ The rod-shaped fibrinogen protein is $~ 45-n m$ long containing two identical outer D domains each connected to the central E domain, which contains the two pairs of fibrinopeptides, by a coiled-coil segment. ${ }^{49}$

In the last step of the coagulation cascade, thrombin cleaves off two sets of peptides, fibrinopeptides A and B, from the amino terminal ends of the $A \alpha$ and $B \beta$ chains which exposes knobs that can interact with holes that are always exposed at the ends of the molecule. Hence, each E-site interacts with a complementary binding site located on the $\mathrm{D}$ domain of adjacent molecules. 


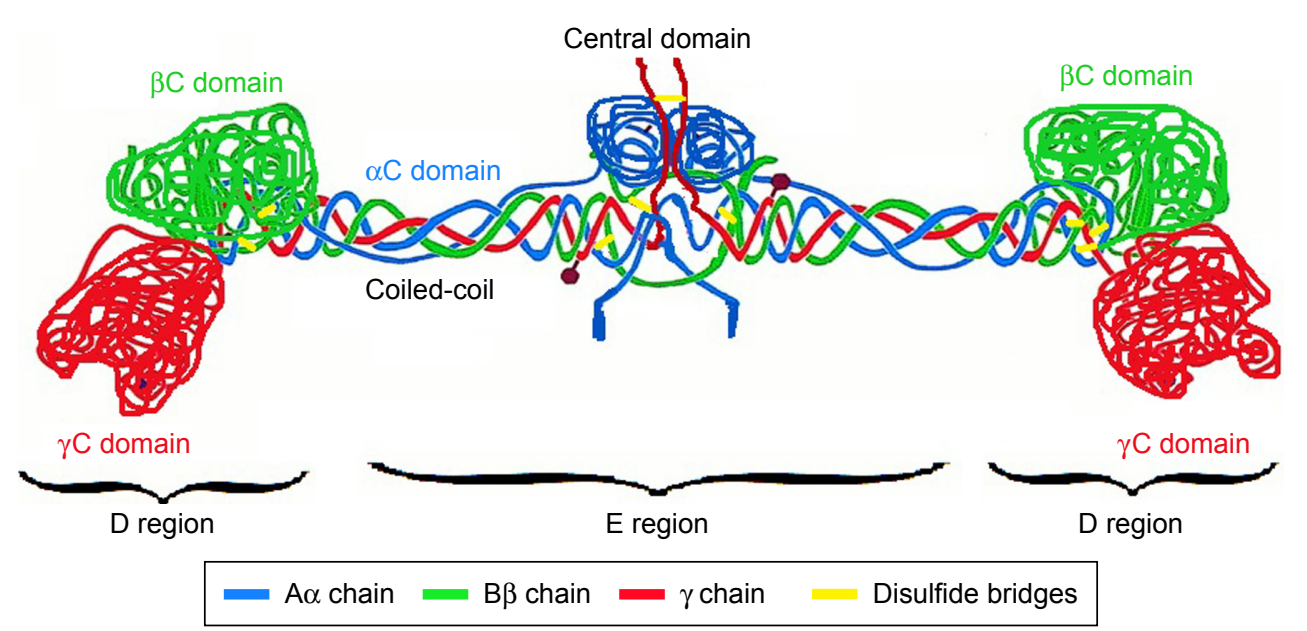

Figure I Fibrinogen structure. A $\alpha$ chains are shown in blue, $B \beta$ chains are shown in green, and $\gamma$ chains are shown in red. Disulfide bridges stabilizing the coiled-coil regions are shown in yellow.

Such "E:D" associations result in the spontaneous formation of half-staggered, double-stranded protofibrils. These protofibrils then aggregate and branch, yielding a three-dimensional (3D) clot network, as shown in Figure 2. ${ }^{47,48}$ Such structures are inherently weak, but the covalent cross-linking of fibrin by factor XIIIa leads to the formation of a stable structure.

The fibrin structure can be described by variables such as thickness of the fibers, number of branch points, porosity, and permeability of the gels. ${ }^{47}$ These parameters vary to a very large extent, depending on the conditions of polymerization such as fibrinogen and thrombin concentrations, salt concentration, $\mathrm{pH}$, temperature, and the presence of other plasma proteins (eg, fibronectin and albumin). ${ }^{48,50-52}$ Clots with thick fibers, few branch points, and large pores are

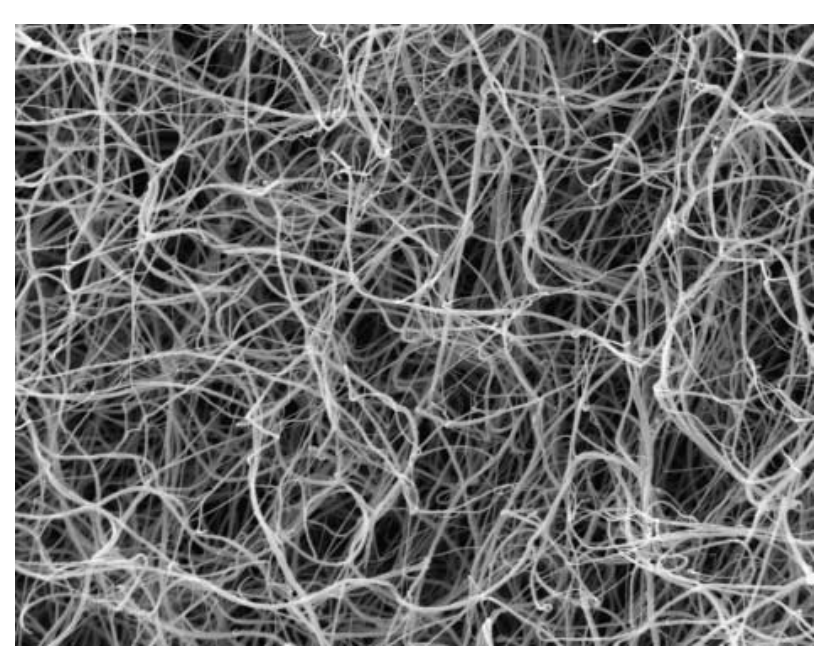

Figure 2 Scanning electron micrograph of $\mathrm{I} \mathrm{mg} / \mathrm{L}$ human fibrinogen polymerized by I $\mathrm{U} / \mathrm{mL}$ thrombin at $\mathrm{pH} 7.4$ and $150 \mathrm{mM} \mathrm{NaCl}$. Full width of the figure is $62.5 \mathrm{~mm}$. Janmey PA, Winer JP, Weisel JW. Fibrin gels and their clinical and bioengineering applications. J R Soc Interface. 2009;6(30): I-10, by permission of The Royal Society. ${ }^{15}$ formed at lower concentrations of thrombin while higher thrombin concentrations tend to yield clots with thin fibers, many branch points, and small pores. ${ }^{15,53}$

\section{Biological properties of fibrin}

The fibrin matrix not only acts as a barrier preventing further blood loss but also provides a temporary scaffold needed to support tissue healing and remodeling. ${ }^{49}$ Moreover, fibrin specifically binds numerous proteins and growth factors resident in normal tissue or is released into the wound in response to wound healing. ${ }^{13,48,49}$ These proteins include ECM proteins such as fibronectin and vitronectin, many growth factors including FGF, VEGF, insulin-like growth factor-1, and enzymes like plasminogen as well as tissue plasminogen activator (tPA). This complex mixture of proteins bind to the fibrin matrix, enabling it to play an active role in wound healing through specific receptor-mediated interactions with cells. ${ }^{13,49}$

\section{Mechanical properties of fibrin}

Fibrin demonstrates unique viscoelastic behavior, that is, the mechanical response depends on the rate and duration of loading. ${ }^{54}$ Stiffness and deformation provide information about the elastic and inelastic behavior of fibrin, respectively. ${ }^{53}$ Fibrin stiffness behavior is a function of the experienced strain, a phenomenon which is called "strain hardening": at low strains, stress is directly proportional to strain, but at large strains, fibrin stiffness rises up to 20 -fold with increasing strain. The study of fibrin deformation reveals that the fibrin network expresses irreversible deformation, but surprisingly, it completely recovers its stiffness after removing the stress. In other words, fibrin is 
an experienced structure, such that there are no net changes in its structure during creep experiments. ${ }^{55} \mathrm{Kim}$ et al found that fibrin exhibits a nonlinear mechanical response to external compression and that its stress-strain curve has three distinct regimes. ${ }^{56}$ First, a linear viscoelastic response to compression can be observed, in which most fibers are straight. Then, a stress plateau follows in which more and more fibers buckle and collapse. Finally, network densification occurs with a stress-strain response that is markedly nonlinear and dominated by bending of fibers after buckling and inter-fiber contact. ${ }^{56}$ The authors in their next study showed that deformation of the fibrin matrix occurs nonuniformly and that as a downward force was applied on the top surface of the clot, the top layers compressed earlier and stronger than the lower network portions. ${ }^{57}$

\section{Fibrin degradation properties}

When the clot is no longer needed, fibrinolysis is activated to efficiently dissolve clots and avoid thrombosis. Plasmin that circulates in the blood as the precursor plasminogen is considered to be the main fibrinolytic enzyme. ${ }^{58}$ Plasminogen adheres to the fibrin clot and is activated to plasmin by the action of plasminogen activators such as tPA that also binds to fibrin. Hence, fibrin has a dual role during fibrinolysis, functioning as both a cofactor and a substrate for the fibrinolytic enzyme plasmin. ${ }^{59}$ Following activation, plasmin cleaves fibrin at specific sites and releases soluble fibrin digestion products into the circulating blood. There are several factors affecting the effectiveness of fibrinolysis in vivo, including the fibrin network structure, the clot hemodynamic environment, the kinetic properties of the fibrinolytic enzymes, and the balance of their formation and inactivation. ${ }^{58}$

\section{Importance of fibrin composition, structure, and properties in bone tissue engineering}

Each component of fibrin may have an important contribution in bone tissue engineering research. Bluteau et al noted that low thrombin concentrations $(0.5-5 \mathrm{U} / \mathrm{mL})$ upregulated the expression of osteoblastic markers and elicited an enhanced angiogenic response of osteoblasts by VEGF expression. ${ }^{60}$ El-Hakim found that injection of factor XIII into the tail of diabetic rats significantly affected the healing process of bone defects that were created in the inferior border of mandible bone probably by stabilizing blood clots or forming stable bonds between the chains of collagen molecules. ${ }^{61} \mathrm{Kim}$ and Lee reported that coating of fibrinogen on the surface of biphasic calcium phosphate (BCP) noticeably enhanced human mesenchymal stem cell (hMSC) proliferation and adhesion, probably due to the surface roughness that was created by the adsorption of fibrinogen and/or by the function of an epitope region of $\beta 15-42$ contained in fibrinogen. Furthermore, in vivo implantation of granules in a rabbit calvarial model revealed a significant improvement in bone healing through the addition of fibrinogen on the BCP surface. This improvement was attributed to the promotion of native fibrin clot formation, enhancement of initial stability of ceramic particles, and the effect of the fibrin matrix on fibroblast and vascular cell migration into the injury site. ${ }^{62}$ Similarly, Santos et al reported that incorporation of fibrinogen into chitosan scaffolds improved bone formation in a critically sized bone defect in rats, which correlated with the elicited immune response. ${ }^{63}$ In another study, ${ }^{64}$ the authors seeded human monocytes on naked chitosan substrates or fibrinogen-coated chitosan and differentiated them into macrophages for 10 days. Results indicated that compared to pure chitosan substrates, fully differentiated macrophages on chitosan/fibrinogen films produced significant amounts of important factors involved in bone and wound healing and angiogenic mediators such as platelet-derived growth factor-BB (PDGF-BB), BMP-5, BMP-7, and FGF-7. The authors concluded that the adsorption of fibrinogen on chitosan films regulated macrophage responses toward a bone remodeling/regenerative phenotype. ${ }^{64}$ Moreover, Linsley et al precoated cell culture plates with fibrinogen $(10 \mathrm{mg} / \mathrm{mL})$ and observed that these substrates were able to support hMSC attachment, proliferation, and early and late osteogenic differentiation especially in osteogenic medium. ${ }^{65}$ Colley et al reported that MSCs that were precultured for 7 days on fibrin and then re-plated onto tissue culture plastic, exhibited superior proliferative, and osteogenic capacity compared to those of cells that were cultured directly on tissue culture plastic. These improvements were more obvious when cells were grown on lower fibrinogen concentrations. The authors provided evidence of better maintenance of the stem-like nature of MSCs that were cultured on fibrin gels made of lower concentrations of fibrinogen. The authors also emphasized the role of mechanical and topological properties as well as ligand density of fibrin gels on their properties. ${ }^{66}$

A change in fibrin properties dramatically influences the behavior of the cells inside it (Table 2). For example, Bensaid et $a{ }^{67}$ reported that MSCs seeded in fibrin scaffolds containing low concentrations of fibrinogen and thrombin $(1.8,9$, and $18 \mathrm{mg} / \mathrm{mL}$ of fibrinogen and 10,50 , and $100 \mathrm{U} / \mathrm{mL}$ of thrombin) were able to spread, proliferate, and express alkaline phosphatase (ALP) while in scaffolds 
Table 2 Control of cell functions within fibrin by changing structural variables

\begin{tabular}{|c|c|c|c|c|}
\hline $\begin{array}{l}\text { Fibrinogen } \\
\text { concentration }\end{array}$ & $\begin{array}{l}\text { Thrombin } \\
\text { concentration }\end{array}$ & Dependent variables & Main findings & References \\
\hline $1.8-90 \mathrm{mg} / \mathrm{mL}$ & $\mathrm{I0}-500 \mathrm{IU} / \mathrm{mL}$ & $\begin{array}{l}\text { Change in fibrinogen and } \\
\text { thrombin concentration }\end{array}$ & $\begin{array}{l}\text { Component concentration dramatically affects cell activity and gel } \\
\text { degradation }\end{array}$ & 67 \\
\hline $5-50 \mathrm{mg} / \mathrm{mL}$ & $2-250 \mathrm{IU} / \mathrm{mL}$ & $\begin{array}{l}\text { Change in fibrinogen and } \\
\text { thrombin concentration }\end{array}$ & $\begin{array}{l}\text { Changing fibrinogen concentration reversely affects hMSC } \\
\text { proliferation and osteogenic differentiation }\end{array}$ & 68 \\
\hline 5,10 , or $20 \mathrm{mg} / \mathrm{mL}$ & $10 \mathrm{IU} / \mathrm{mL}$ & $\begin{array}{l}\text { Change in fibrinogen } \\
\text { concentration }\end{array}$ & $\begin{array}{l}\text { In the presence of ceramics, greatest cell growth is detected in } \\
\text { highest fibrinogen concentration }\end{array}$ & 72 \\
\hline $10-80 \mathrm{mg} / \mathrm{mL}$ & $5 \mathrm{U} / \mathrm{mL}$ & $\begin{array}{l}\text { Change in fibrinogen } \\
\text { concentration }\end{array}$ & $\begin{array}{l}\text { In the presence of bone powder, hMSC proliferation and osteogenic } \\
\text { differentiation are increased by increasing fibrinogen concentration }\end{array}$ & 73 \\
\hline $5 \mathrm{mg} / \mathrm{mL}$ & $0.25-4 \mathrm{U} / \mathrm{mL}$ & $\begin{array}{l}\text { Change in thrombin } \\
\text { concentration }\end{array}$ & $\begin{array}{l}\text { Thrombin dose-dependently increased osteoblast differentiation by } \\
\text { modulation of the fibronectin-binding capacity of fibrin }\end{array}$ & 74 \\
\hline $40 \mathrm{mg} / \mathrm{mL}$ & $5 \mathrm{U} / \mathrm{mL}$ & $\begin{array}{l}\text { Increasing ionic strength } \\
\text { of the fibrinogen solution }\end{array}$ & $\begin{array}{l}\text { Both osteogenic differentiation of entrapped hMSCs and physical } \\
\text { properties of the final gel were improved }\end{array}$ & 50 \\
\hline $4 \mathrm{mg} / \mathrm{mL}$ & $2.5 \mathrm{U} / \mathrm{mL}$ & $\begin{array}{l}\text { Tensile stress applied to } \\
\text { fibrin gels }\end{array}$ & $\begin{array}{l}\text { BMSCs were cultured in a strained fibrin gel, exhibited a specific } \\
\text { orientation which was identical to the strain direction }\end{array}$ & 78 \\
\hline
\end{tabular}

Abbreviations: hMSC, human mesenchymal stem cell; BMSC, bone marrow-derived stromal cell.

containing higher concentrations of respective components (45 and $90 \mathrm{mg} / \mathrm{mL}$ for fibrinogen and 250 and $500 \mathrm{U} / \mathrm{mL}$ for thrombin), the cells failed to do so. Researchers explained that at high concentrations of precursors, the fibrin gel may be too dense to allow for cell activities. ${ }^{67}$ In another study, Catelas et $\mathrm{al}^{68}$ noted that the proliferation of hMSCs increased in clots formed from a low fibrinogen concentration, while their osteogenic differentiation potential increased in formulations containing high fibrinogen concentrations. The authors suggested that the higher proliferation of cells is a result of a more open structure for the low fibrinogen concentration, and promotion of the differentiation of the cells at higher fibrinogen concentrations perhaps is caused by the presence of more growth factors contained in the fibrinogen component, ${ }^{68}$ although other investigators have argued that there are no growth factors in commercial fibrin sealant components. ${ }^{69}$ The same group in a separate study detailed the effects of the gel component concentration on the morphology of hMSCs.

Confocal microscopy images of hMSCs revealed that cells in gels with low fibrinogen concentrations $(5 \mathrm{mg} / \mathrm{mL})$ were elongated and spindle-like, but at high fibrinogen concentrations $(50 \mathrm{mg} / \mathrm{mL})$, the cells mostly appeared rounded. At intermediate concentrations, both elongated and rounded morphologies were observed. ${ }^{70}$ Migration of cells from a fibrin matrix also depends on its formulation. Hale et al documented that MSC migration from fibrin hydrogels increased by the dilution of the fibrinogen component for both single-donor and commercial fibrin glues. ${ }^{71}$ However, in vitro and in vivo outcomes may be different when fibrin is used in combination with other biomaterials rather than fibrin alone. For example, Linsley et al showed that while hMSC growth in pure fibrin scaffolds decreased with increasing fibrin concentration, in the presence of BCP ceramics, the trend was reversed and greatest cell growth was detected in the highest fibrin concentration. ${ }^{72} \mathrm{Kim}$ et al mixed demineralized bone powder and various fibrinogen concentrations $(10,20,40$, or $80 \mathrm{mg} / \mathrm{mL})$ by $5 \mathrm{U} / \mathrm{mL}$ thrombin and showed that the proliferation and expression of osteoblastic markers of hMSCs were enhanced in scaffolds prepared from higher fibrinogen concentrations. ${ }^{73}$ However, it is necessary to point out that there was a noticeable decrease in the growth rate of cells cultured on the scaffolds fabricated with $80 \mathrm{mg} / \mathrm{mL}$ fibrinogen, probably due to lower porosity of the scaffolds and the results may vary if the cell culture duration time increased. In agreement with this study, Abiraman et al reported that when bioactive glass or calcium phosphate calcium silicate granules that were coated by $5 \mathrm{mg}$ fibrin glue were implanted into the muscles of mice, greater bone formation was observed than when granules were coated by $2.5 \mathrm{mg}$ fibrin glue. ${ }^{19}$

To understand the mechanism of such cellular behavior, Oh et $\mathrm{al}^{74}$ prepared fibrin matrices by mixing $0.25-4 \mathrm{U} / \mathrm{mL}$ of thrombin and $5 \mathrm{mg} / \mathrm{mL}$ of fibrinogen. The authors differentiated MC3T3-E1 osteoblast-like cells inside matrices and observed that thrombin dose-dependently increased osteoblast differentiation. This behavior was correlated to thrombin-induced alterations in the fibrin structure. They also provided evidence suggesting that thrombin modulated the fibronectin-binding capacity of fibrin through enlargement of surface area and/or exposure of the cryptic fibronectinbinding sites in fibrinogen. ${ }^{74}$ The key role of the fibronectinbinding capacity of fibrin on cellular functions is supported by outcomes from other studies. Oh et $\mathrm{al}^{75}$ showed that although the level of the total serum protein adsorption to fibrin was similar to that of collagen, the fibrin glue adsorbed 
fibronectin $\sim 6.7$ times more. Their result also revealed that fibrin stimulated both the proliferation and differentiation of osteoblasts at higher levels compared to collagen. ${ }^{75}$

In addition to the mechanism of action, it should be pointed out that decreasing fibrinogen and thrombin concentrations negatively affects the mechanical and degradation properties of fibrin hydrogels. For instance, Bensaid et $\mathrm{al}^{67}$ found that the gels prepared from $9 \mathrm{mg} / \mathrm{mL}$ fibrinogen and $50 \mathrm{U} / \mathrm{mL}$ thrombin resorbed quickly and completely disappeared within 15 days in vitro. In contrast, gels prepared with $90 \mathrm{mg} / \mathrm{mL}$ fibrinogen and $500 \mathrm{U} / \mathrm{mL}$ thrombin concentrations did not exhibit any detectable macroscopic degradation during the same time period ${ }^{67}$ Hence, in a different approach and to enhance both physical and biological properties of a fibrin gel, Davis et al increased the ionic strength of the fibrinogen solution through supplementation with sodium chloride $(\mathrm{NaCl})$ before gelation and successfully improved both osteogenic differentiation of entrapped hMSCs and physical properties of the final gel. ${ }^{50}$ Physiological concentrations of fibrinogen and thrombin also provided a slow gelation time, which prevented mechanical stress and osmotic shock of the entrapped cells. Noticeably, these low concentrations of fibrin constituents can be prepared from an autologous origin. In another study, the authors used such procedures to simultaneously improve the pro-angiogenic and osteogenic potential of entrapped MSCs in fibrin gels. ${ }^{76}$ Furthermore, because human umbilical cord blood endothelial colony forming cells (ECFCs) produce BMP-2 as a paracrine signaling molecule, the addition of ECFCs to the system resulted in increased osteogenic potential compared with a monoculture of MSCs.

An alternative approach to manipulate structure and control cell functions within fibrin gels is to use mechanical force. It is well documented that fibrin, in a state of nature, exhibits a mesh-like structure composed of fibrils with no specific orientation. ${ }^{53}$ However, Matsumoto et al reported that after applying a continuous mechanical force, clots displayed bundle-like structures with fibrils that were oriented parallel to the strain direction. ${ }^{77}$ In a later work by the same group, bone marrow-derived stromal cells (BMSCs) were cultured in a strained fibrin gel and exhibited a specific orientation which was identical to the strain direction, suggesting that structural changes in the gel provided contact guidance cues to promote cell alignment. Moreover, the direction of the cell proliferation as well as mineral deposition in the strained gel was restricted to the same direction. The authors attributed this observation to tightly aggregated fibrin fibrils having no spaces or pores within its bundles and therefore inhibited random cell migration and mineral deposition. However, control of cell function was not limited to structural features, as the authors mentioned that a more rigid gel enhances osteoblast proliferation, whereas less rigid fibrin gels promotes differentiation. ${ }^{78}$ In another study, they noted that these fibrin gels induced the formation of cortical bone-like tissue after subcutaneous implantation into mice, while implantation of control gels induced bone tissues with disordered structures (Figure 3). ${ }^{79}$ Numerous proactive nanoscale surface features can be noticed after straining.
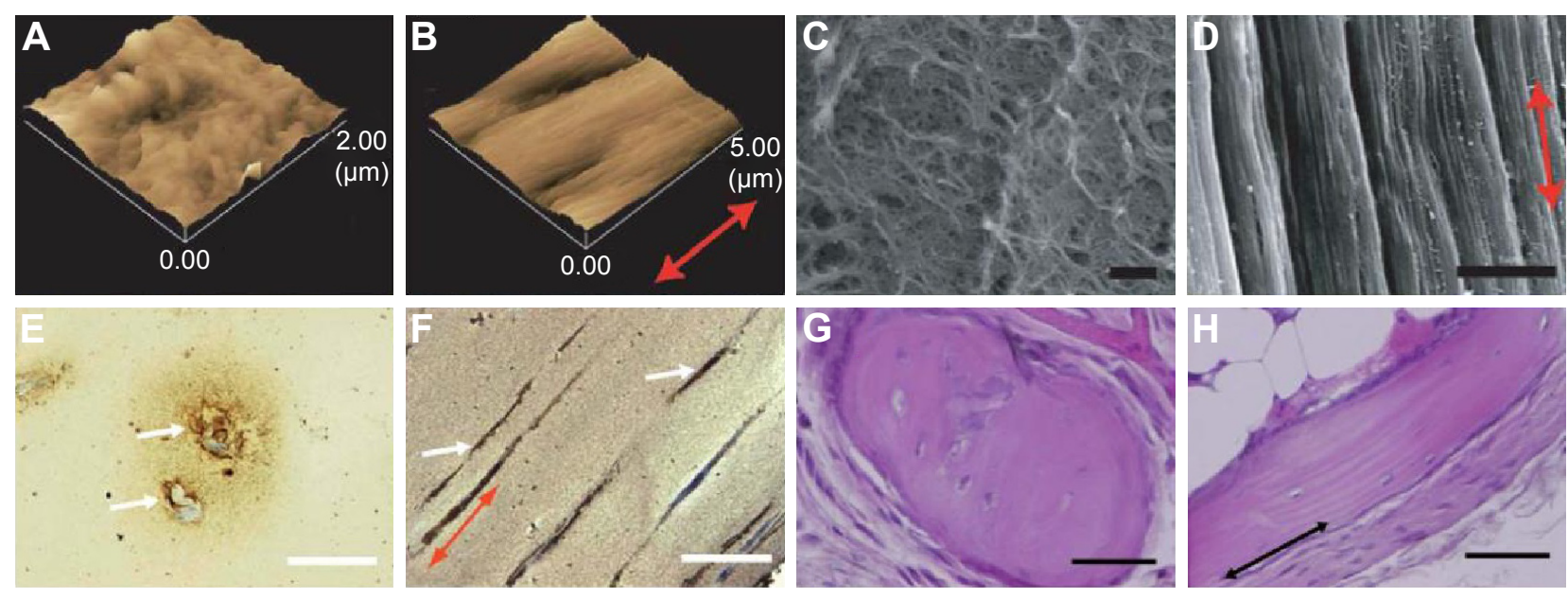

Figure 3 AFM images of a control fibrin gel (A) and a strained fibrin gel (B). Scanning electron microscopy images of a control fibrin gel (C) (bar: I $\mu$ m) and bundle-like structures formed in a strained fibrin gel (D) (bar: $5 \mu \mathrm{m}$ ). Reproduced from Matsumoto T, Sasaki J-I, Alsberg E, Egusa H, Yatani H, Sohmura T. Three-dimensional cell and tissue patterning in a strained fibrin gel system. PLoS One. 2007;2(I I):el211. ${ }^{77}$ Mineral depositions of contained mouse BMSCs detected by von Kossa staining of a control gel (E) and strained gel (F) (bar: $50 \mu \mathrm{m}$ ). Reproduced from ${ }^{78}$ with permission of The Royal Society of Chemistry. H\&E stained images of ectopic bone formation by nonstatic (G) and static (H) fibrin gels. Implanted fibrin gels were harvested at 6 weeks after implantation in mice (bar: $50 \mu \mathrm{m}$ ). Reproduced from Sasaki JI, Matsumoto T, Imazato S. Oriented bone formation using biomimetic fibrin hydrogels with three-dimensional patterned bone matrices. J Biomed Mater Res A. 20I5; 103(2):622-627.79 The arrows indicate the mechanical force direction.

Abbreviations: AFM, atomic force microscopy; BMSCs, bone marrow-derived stromal cells; H\&E, hematoxylin and eosin. 
Another issue that requires attention is fibrin degradation rate. It has been shown that faster degrading of fibrin increases the expression of osteogenic markers by both MSCs and MG63 cell line while decreasing their proliferation. ${ }^{80}$ However, fast degradation of fibrin does not give enough time for osteogenic cells to differentiate and produce their own matrix and fill the defect site. The addition of protease inhibitors into the matrices is a common method to prolong fibrin degradation time. Le Guehennec et al provided evidence that a minimal concentration of aprotinin, a potent competitive inhibitor for the active site of plasmin, is necessary for obtaining a stable fibrin scaffold onto which the bone cells can colonize and generate new bone. ${ }^{81}$ However, because of its small size (58 amino acids, $6.5 \mathrm{kDa}$ ), aprotinin can readily diffuse out of the fibrin resulting in the loss of gel protection. ${ }^{82,83}$ Researchers have tried to circumvent this problem by chemically conjugating aprotinin to fibrinogen ${ }^{82}$ or by covalently crosslinking an engineered aprotinin variant into the fibrin matrix. ${ }^{83}$ Despite these promising efforts, the suitability of aprotinin as a fibrinolysis inhibitor is debatable because of its heterologous origin that has occasionally been associated with adverse reactions or even death in humans. ${ }^{84}$ To avoid these potential risks, tranexamic acid has been proposed as a safe alternative to this fibrinolysis inhibitor. Tranexamic acid is a synthetic derivative of the amino acid lysine that competitively inhibits the activation of plasminogen to plasmin.$^{84}$ Demol et al observed that supplementation of $0.5 \mathrm{mg} / \mathrm{mL}$ of tranexamic acid in culture medium successfully stabilized the fibrin hydrogels without affecting the activity of the encapsulated cells. ${ }^{85}$ Jegoux et al compared the efficiency of aprotinin and tranexamic acid and concluded that both the inhibitors led to equivalent bone regeneration both qualitatively and quantitatively. ${ }^{86}$

\section{Fibrin preparation}

Fibrin sealants can be prepared at industrial scales by the fractionation of large pools of plasma or from single plasma donations by blood establishments or hospital blood banks. ${ }^{87}$ The procedure for the preparation of the majority of commercial fibrin involves either thawing of the frozen plasma at $2^{\circ} \mathrm{C}-4^{\circ} \mathrm{C}$ (cryoprecipitate) or precipitation of plasma proteins with $10 \%$ ethanol (Cohn fraction I). ${ }^{69,88}$ The manufacturing process may lead to co-purification of other plasma proteins such as fibronectin, factor XIII, and von Willebrand factor (vWF). ${ }^{88}$ Adjustment of the concentration of the fibrinogen, typically to $>80 \mathrm{~g} / \mathrm{L}$, is achieved by ultrafiltration. ${ }^{69}$

Thrombin is also generated at industrial scales from pooled plasma in several steps. First, prothrombin is isolated from plasma by cryoprecipitation and several chromatography steps. Prothrombin is then activated to thrombin, purified by chromatography and concentrated to $500-1,000 \mathrm{IU} / \mathrm{mL}$ by ultrafiltration. ${ }^{69,89}$

Fibrin can also be prepared from single-donor plasma either from autologous or allogeneic origin. A number of different methods can be used to isolate fibrinogen from plasma (Figure 4). These include cryoprecipitation or chemical precipitation with ethanol, ammonium sulfate, or poly(ethylene glycol)..$^{16,90}$ The principal advantage of cryoprecipitation over other procedures is that no potentially cytotoxic chemicals are required for this process; however, it is time-consuming and the fibrinogen yield is extremely low. Cryoprecipitation is time-consuming but chemical precipitation is rapid. However, purity of the final product is a concern. ${ }^{16,90}$ There are also methods and devices to generate thrombin from a single donation of plasma. ${ }^{87,91}$

Several considerations must be taken in account when selecting the appropriate fibrin glue for scaffold fabrication (Table 3). Commercially produced fibrin glue is available at a standardized quality, whereas single-donor fibrin glue suffers from batch-to-batch variability. Moreover, singledonor fibrin glues offer lower fibrinogen concentrations, less cross-linking of fibrin fibers, and poorer resistance to clot lysis compared to commercial fibrin glues..$^{92}$ But a singledonor fibrin glue does have some major advantages over commercial ones. First, the possibility of viral transmission is greatly reduced with the use of an autologous fibrin glue. ${ }^{93}$ Furthermore, the steps used to inactivate pathogens may affect the biological properties of the final product. ${ }^{94}$ The cost of a single-donor glue is another factor that is much lower than commercial fibrin. ${ }^{93}$

In addition, single-donor plasma can be prepared from platelet-rich plasma in which platelets present huge reservoirs of growth factors that may enhance bone repair. ${ }^{95}$ In this regard, Xuan et al showed that fibrin prepared from autologous platelet-rich plasma, as an adjunct to Bio-Oss ${ }^{\circledR}$ particles for maxillary sinus augmentation of dogs, significantly increased bone formation in the graft sites compared to the case of Tisseel ${ }^{\circledR} .96$

\section{Different forms of fibrin applications in bone tissue engineering}

In bone tissue engineering, fibrin glue is often used as beads and microbeads, coating agents on other scaffolds, pre-formed scaffolds, or injectable hydrogels. In the following sections, these different applications are described. 


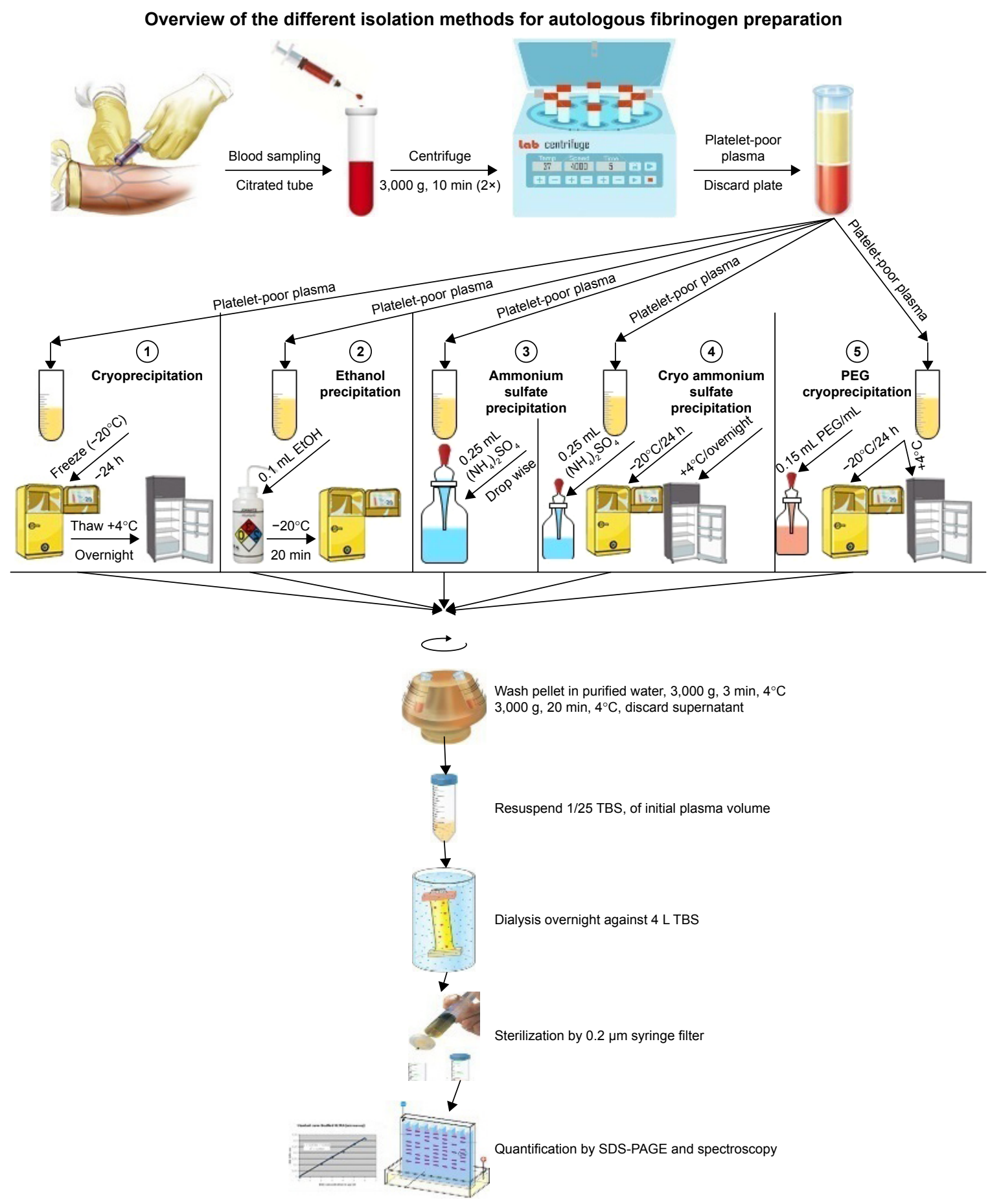

Figure 4 Different methods used to isolate fibrinogen from plasma.

Abbreviations: EtOH, ethanol; PEG, poly(ethylene glycol); SDS-PAGE, sodium dodecyl sulfate polyacrylamide gel electrophoresis; TBS, Tris-buffered saline.

Fibrin beads for bone tissue engineering Made of extensively cross-linked and partially denatured fibrin, fibrin microbeads (FMBs) have been used to improve the biodegradability of matrices while retaining their high celladhesion properties. ${ }^{97}$ In a typical procedure, FMBs are synthesized by oil-stirring of a fibrinogen and thrombin mixture at $65^{\circ} \mathrm{C}-75^{\circ} \mathrm{C}$ for $6-8$ hours and stored as a dry powder. ${ }^{98} \mathrm{At}$ this high temperature, fibrinogen denatures while factor XIIIa can remain active and cross-link proteins. Due to the conformational transformations of fibrinogen at these high temperatures, FMBs are highly haptotactic to various cell types, including osteogenic bone marrow-derived progenitors. ${ }^{99,100}$

For bone tissue engineering studies, the obtained FMBs were incubated for 2 days in a suspension containing whole 
Table 3 Advantages and disadvantages of single-donor and commercial fibrin glue

\begin{tabular}{lll}
\hline & Pros & Cons \\
\hline Commercial & - Standardized quality & - Risk of viral transmission \\
fibrin glue & - High tensile strength & - Expensive \\
& - Available & - Reduced bioactivity \\
Single-donor & - Cheap & - Batch-to-batch variability \\
fibrin glue & - Safe & - Less cross-linking of \\
& - Can be prepared from & fibrin fibers \\
& platelet-rich plasma & - Low tensile strength \\
\hline
\end{tabular}

bone marrow (from mice or rats) and subsequently a high number of mesenchymal cells attached to them. In vitro and in vivo analysis demonstrated the osteogenic potential of the isolated cells..$^{97,98,101}$ Next, authors cultured FMB-MSCs constructs in osteogenic medium and obtained a bone-like structure which was implanted into a mouse skull defect. After 2 months, results showed that defects filled with bone-like tissue had a $\mathrm{Ca} / \mathrm{P}$ ratio similar to that of the native bone while no repair was seen in the control animals without implants or when the defect was filled with FMBs alone. ${ }^{102}$ In addition to efficiently repairing bone, the use of FMBs successfully eliminated stages of culturing the MSCs on tissue culture plastics, trypsinizing the cells that can damage their cellular membrane receptors, performing cell passages, and finally loading the cells onto the scaffolds. ${ }^{102}$ Furthermore, FMBs may be used as a matrix onto which cells can be maintained for a long time at room temperature. The matrix preserves their proliferation and bone differentiation potential, which in turn facilitates cellular transformation between different research and/or clinical centers. ${ }^{103}$

Despite these promising results, in these studies, cells were seeded onto the surface of the beads rather than being encapsulated inside the microbeads. ${ }^{32}$ In an effort to encapsulate periosteal cells inside fibrin, Perka et al fabricated cell-encapsulating fibrin beads $\sim 3 \mathrm{~mm}$ in diameter. ${ }^{104,105}$ The constructs were then implanted into ulna defects of rabbits. After 28 days, analysis revealed greater bone healing in cell-encapsulating fibrin bead groups compared to control groups with fibrin beads alone or untreated defects. ${ }^{104}$ The same authors in their future study noted that the addition of $\alpha$-TCP particles to fibrin beads improved both proliferation and differentiation of osteoblasts. ${ }^{106}$ However, injectability of these large beads is an important concern. ${ }^{32}$ In another approach, Zhou et al ${ }^{107}$ developed alginate-FMBs with sizes of several hundred micrometers to encapsulate human umbilical cord mesenchymal stem cells (hUCMSCs). They demonstrated that the addition of a small amount of fibrin to the alginate microbeads greatly enhanced their degradation.
The authors explained that fibrin may lose the alginate structure resulting in mechanically weaker microbeads that were readily degradable and/or fibrin enhanced cell attachment and proliferation in the microbeads which in turn increased the internal pressure of microbeads and accelerated their breakdown. Moreover, the released hUCMSCs exhibited excellent proliferation, osteogenic differentiation, and bone mineral synthesis features. ${ }^{32,107}$ The same group, in a series of subsequent studies, mixed stem cell-encapsulating microbeads with a calcium phosphate cement (CPC) paste, where the microbeads could protect the cells from the mixing and injection forces. They noted that alginate-FMBs embedded in a CPC surface ${ }^{107}$ or completely wrapped inside the CPC paste ${ }^{108}$ and were able to quickly release the hUCMSCs that were attached to CPC. They also showed that incorporation of fibronectin and Arg-Gly-Asp into the CPC paste greatly improved cellular functions. Later, the released cells differentiated into an osteogenic lineage as indicated by the synthesis of bone minerals. ${ }^{107,109}$

\section{Fibrin as a coating agent in bone tissue engineering}

Due to the poor mechanical properties of fibrin sealants, many authors have frequently coated fibrin on more mechanically stable materials such as metals, polymers, and bioceramics. In these systems, the main function of fibrin was to facilitate cell/growth factor attachment and distribution within the entire scaffolds.

Zhu et $\mathrm{al}^{110}$ showed that the addition of fibrin to the culture medium during seeding of hBMSCs into $\mathrm{CaCO}_{3}$ scaffolds resulted in higher seeding efficiency as well as a more uniform distribution of cells throughout the scaffolds compared to seeding in culture medium alone. The polymerization of fibrinogen during seeding which prevented the cells from exiting the scaffold and the capacity of the fibrin glue to bind to cells possibly resulted in these effects. ${ }^{110}$ The same group in a different study showed that the use of fibrin positively affected the osteogenic differentiation and angiogenic activity of the seeded cells by sustaining the expression of osteocalcin (OC) and VEGF, respectively. However, the maximum level of expression of OC and VEGF in hBMSCs did not increase through the use of fibrin. ${ }^{111}$ Kneser et al ${ }^{42}$ immobilized osteogenic cells in fibrin and seeded them into a processed bovine cancellous bone (PBCB) matrix. Later, scaffolds with and without cells were implanted into a rat calvarial defect. After 1 month, a low survival rate of transplanted cells especially in the central parts of scaffolds was observed, and no significant 
differences in the process of bone healing was seen between the two groups. ${ }^{42}$ In another study, Steffens et al co-seeded human endothelial cells and primary osteoblasts into PBCBbased scaffolds to investigate whether a blood vessel network which was created by endothelial cells may enhance survival of osteogenic cells. ${ }^{43}$ Despite some preliminary promising results toward the formation of a $3 \mathrm{D}$ network of perfused human neovessels in chick embryo chorioallantoic membrane and subcutaneous mouse models, promotion of bone repair was not detected in the calvarial bone defects in mice. The authors postulated that endogenous neovascularization in the defects may have been sufficient to sustain osteogenesis. ${ }^{112}$

Nair et $\mathrm{al}^{113}$ cultured BMSCs on bare or fibrin-coated bioactive ceramics made of hydroxyapatite (HA) and silicacoated HA cylinders for up to 28 days. Analysis of cell viability, morphology, proliferation, cell cycle assay, and differentiation showed that the fibrin considerably enhanced cellular functions. ${ }^{113}$ Abiraman et al reported that bone formation occurs in quadricep muscles of mice only when fibrin is coated on bioactive glass and calcium phosphate calcium silicate granules. ${ }^{19}$ Kalia et al ${ }^{114}$ sprayed autologous MSCs, suspended within fibrin glue, onto HA-coated collars of Ti-Al $(6 \%) \mathrm{V}(4 \%)$ prostheses and inserted the implants into the tibia of sheep. After 6 months, radiographical and histological analyses showed that bone growth and bone contact to the implant surface increased by using MSCs and fibrin. ${ }^{114}$

Fibrin has also been coated on bioinert metallic implants to enhance cell distribution and response and to release growth factors. Kopf et $\mathrm{al}^{115}$ noted that preincubation of $\mathrm{Ti}$ surfaces with whole human blood led to an increased number of attached cells, enhanced ALP and collagen-I protein expression, and promoted mineralization. These improvements in cell behavior were attributed to the creation of a $3 \mathrm{D}$ fibrin network on Ti surfaces and/or the release of cytokines that were embedded within the platelets in the fibrin matrix. ${ }^{115}$ Spear et $\mathrm{al}^{25}$ showed that fibrin deposition on porous networks composed of 444 ferromagnetic stainless steel fibers significantly influenced infiltration of human osteoblasts within the scaffolds. For control samples without fibrin, cells with well-spread morphologies were observed only on the metallic fiber surfaces and junctions, while fibrin-containing samples showed cell attachment over and between the fibers. ${ }^{25}$ In another work, BMP-2 containing fibrin gels were used to fill porous $\mathrm{Ti}$ implants and repair critical-sized segmental femoral bone defects in rats. It is important to note that bone regeneration did not occur in control groups wherein defects were filled with empty Ti or fibrin-filled scaffolds. In other words, fibrin alone did not improve the bone regeneration potential of Ti implants but served as a delivery vehicle for BMP-2 that improved the bone repair process. ${ }^{26}$ Fibrin can also be employed to simultaneously deliver osteogenesis and angiogenesis growth factors when incorporated into porous metallic implants. ${ }^{27}$ Some other researchers have argued that constructing 3D scaffolds of natural polymers on metallic implants, rather than providing a thin coating, resembles the architecture of the native bone matrix more closely. Soumya et al created a 3D fibrin/alginate scaffold on Ti plates and noted that this modification improved hMSCs adhesion, proliferation, and subsequent differentiation into osteoblasts (Figure 5). ${ }^{34}$

In the case of synthetic polymers, Kang et $\mathrm{al}^{37}$ coated the surface of poly caprolactone (PCL)/poly(lactic-co-glycolic acid) PLGA scaffolds with a mixture of fibrin and hyaluronic acid and used the obtained constructs as a delivery system for both BMP-2 and adipose-derived stromal cells (ASCs). Results showed that the coating of a scaffold with fibrin/ hyaluronic acid significantly enhanced initial cell attachment without affecting the porosity of the scaffold. In addition,
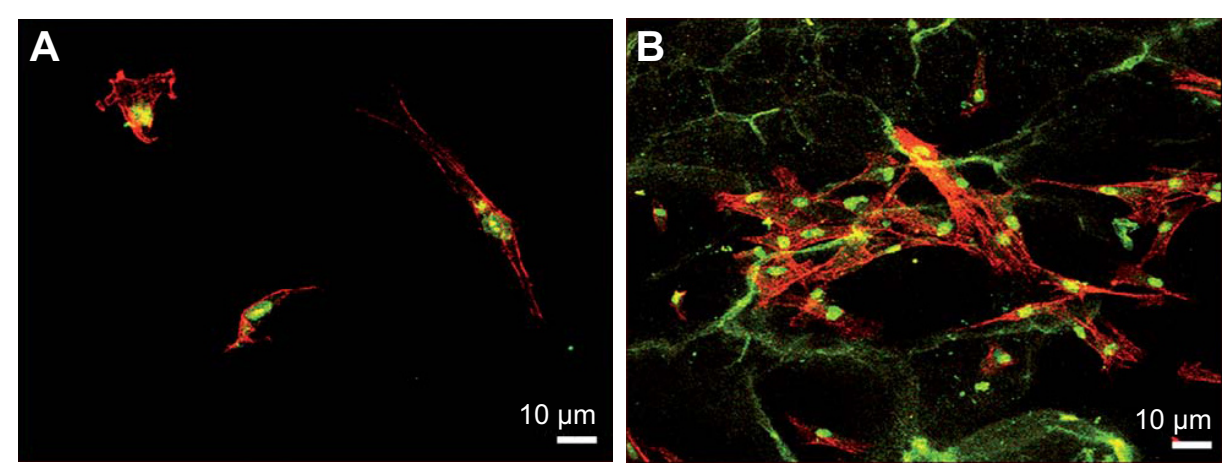

Figure $\mathbf{5}$ Confocal microscopic images of actin-stained hMSCs on (A) control Ti and (B) modified Ti after $6 \mathrm{~h}$ of incubation. The interpenetrating network of fibrin alginate scaffolds can be clearly seen on the modified Ti plate with the cells exhibiting a well spread morphology with a highly organized actin cytoskeletal arrangement than for the control plate. Reproduced from Soumya S, Sreerekha P, Menon D, Nair SV, Chennazhi KP. Generation of a biomimetic 3D microporous nano-fibrous scaffold on titanium surfaces for better osteointegration of orthopedic implants. J Mater Chem. 2012;22(5):1904-1915 with permission of The Royal Society of Chemistry. ${ }^{34}$ Abbreviation: hMSC, human mesenchymal stem cell. 
ALP activity of ASCs seeded on the scaffold and ectopic bone formation in the mouse model was significantly improved by the coating. ${ }^{37}$

Schantz et al, ${ }^{116}$ in a different study, seeded BMSCs or calvaria-derived osteoblasts within a fibrin matrix into the PCL scaffolds. Cell culture analysis revealed continuous cell proliferation, osteogenic differentiation of the cells, and homogeneous cell distribution within the PCL scaffolds. ${ }^{116}$ Furthermore, PCL scaffold-cell constructs showed greater bone regeneration compared to non-seeded PCL scaffolds when implanted into critically sized calvarial defects in rabbits. ${ }^{117}$ The same group further demonstrated that incorporation of osteoconductive calcium phosphate micro-particulates into PCL/fibrin scaffolds significantly improved cell attachment, proliferation, and differentiation into mineralized tissue. ${ }^{35}$ However, some other researchers argued that in addition to osteoconductive scaffolds (composites of PCL and tricalcium phosphate) and osteogenic cells (BMSCs), a minimal amount of osteoinductive growth factors (BMP-2) is necessary to achieve successful bone formation in some situations such as defects in a posterolateral spinal fusion model. ${ }^{118}$

Fibrin may also be useful to improve the behavior of cells on other natural polymers. Conjunction of fibrin on chitosan/nano $\beta$-TCP composites markedly improved cellular functions on scaffolds including MSC attachment, density, proliferation, differentiation, and mineralization. ${ }^{1{ }^{19}} \mathrm{Kim}_{\mathrm{et}} \mathrm{al}^{31}$ added different fibrin concentrations on collagen sponge scaffolds and noted that although the porosity and wateruptake ability were slightly reduced at high fibrinogen concentrations, the attachment, proliferation, and differentiation of cells were enhanced as evaluated by scanning electron microscopy (SEM) images, DNA content assays, and ALP activity, respectively. Authors attributed these improvements to an enlargement of surface area as a result of fibrin fibril formation and increased confluence between the cells (Figure 6). ${ }^{31}$ Another explanation may be increases in fibronectin adsorption that in turn enhanced cell functions as shown by $\mathrm{Oh}$ et al. ${ }^{74}$ However, these results are in contrast to Weinand et al who reported a superior bone formation ability of collagen I compared to fibrin glue, when these hydrogels were coated on porous $\beta$-TCP scaffolds. ${ }^{18}$

Some researchers have tried to combine tissue engineering approaches with genetic therapy to improve bone repair. In this context and to trigger a continued localized presence of an endogenously produced BMP-7, Schek et al ${ }^{120}$ seeded transduced fibroblasts on solid free form-fabricated scaffolds by a fibrin gel or a poly-lactic acid sponge. The constructs were implanted subcutaneously into mice, and 4 weeks later, fibrin gels had a superior ability as a carrier by producing 2-4 times as much bone as the polymer sponge. ${ }^{120}$ Yuan et al $^{121}$ developed a hybrid scaffold of nanocalcium sulfate (nCS) discs and fibrin containing BMP-2-producing BMSCs. To promote angiogenesis during bone formation, they also engineered two fusion proteins, VEGF and FGF9, with the fibrin binding sequence NQEQVSP to enable covalent binding of growth factors to fibrin by the action of FXIII during polymerization. The obtained constructs were implanted subcutaneously into mice, and 8 weeks later, results showed that the conjugation of FGF9 and VEGF in fibrin enhanced neovascularization and bone formation $>4$-fold compared to $\mathrm{nCS}$ with BMSC. ${ }^{121}$
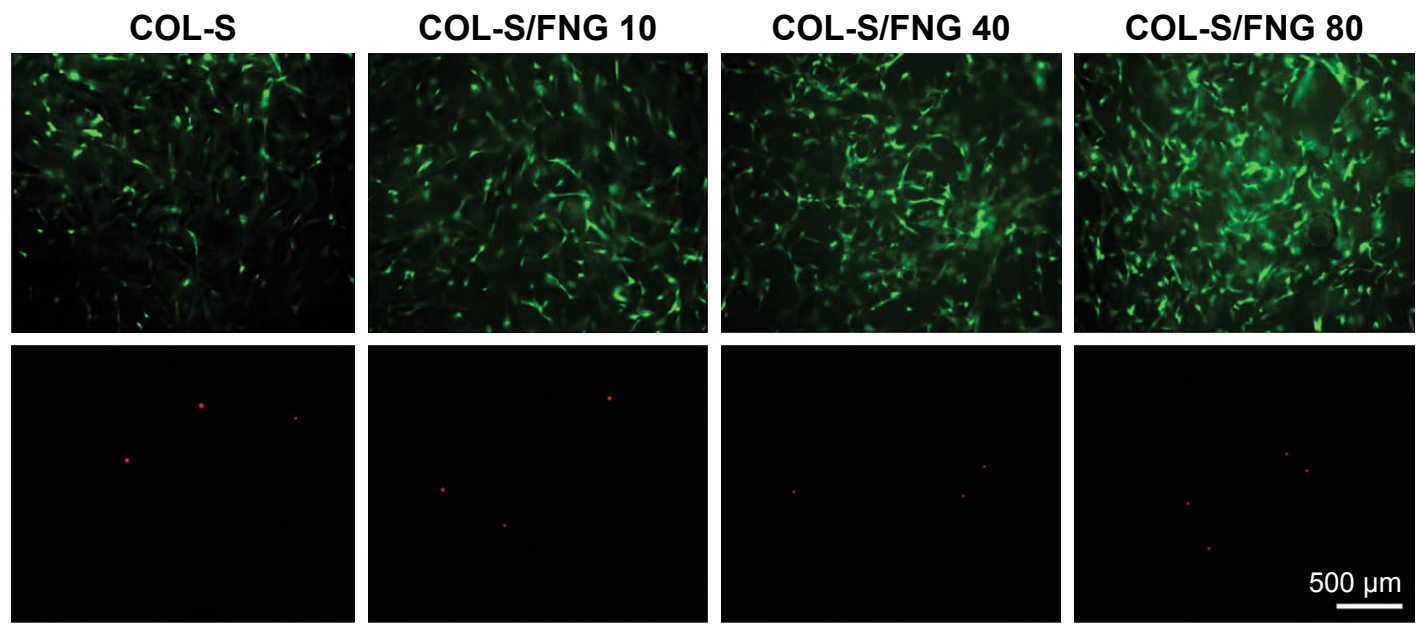

Figure 6 Live/dead fluorescence imaging of MG-63 cells cultured on collagen sponges (COL-S), COL-S/fibrinogen (FNG) I0, COL-S/FNG 40, and COL-S/FNG 80 scaffolds in normal growth media. The viability/cytotoxicity assay was performed after 5 days of culture. Live and healthy cells were stained green by calcein acetoxymethyl (Calcein AM), and dead cells were stained red by ethidium homodimer-I (EthD-I). Copyright (C) John Wiley and Sons. Reproduced from Kim BS, Kim JS, Lee J. Improvements of osteoblast adhesion, proliferation, and differentiation in vitro via fibrin network formation in collagen sponge scaffold. J Biomed Mater Res A. 20I3; I0I (9):266I-2666. ${ }^{31}$ 


\section{Pre-formed fibrin scaffolds}

Despite many beneficial features of injectable fibrin hydrogels, the precise control over the microarchitecture of these materials is not possible. Hence, some researchers have focused on developing fibrin scaffolds with a controlled microstructure. Since these scaffolds are often nanofibrous, they are discussed in detail in the "Application of nanotechnology in fibrin-based bone tissue engineering" section.

\section{Injectable fibrin-based tissue engineering}

Injectable fibrin hydrogels have been extensively investigated for applications in bone tissue regeneration due to their minimally invasive implant procedure, shortened healing time, reduced patient discomfort, and complications along with a decrease in health care costs. Moreover, they can easily fill irregular-shaped defects. Although fibrin possesses fascinating features, fibrin alone is not capable to heal bone defects, ${ }^{26,152,169}$ and it is necessary to mix fibrin with other components such as biological bone grafts, osteoconductive biomaterials, osteogenic cells, and bioactive molecules.

The combination of a fibrin glue with an autologous bone graft to repair bone defects has been shown to improve surgical handling of graft particles and prevent their displacement or movement during the surgery. ${ }^{122,123}$ Giannini et al provided evidence of a favorable improvement in bone regeneration, along with reduced infections and length of hospital stays upon the combination of autologous bone fragments with a mixture of platelet concentrates and a cryoprecipitate fibrin glue. ${ }^{124}$ Tayapongsak et al also noted acceleration of revascularization and stimulation of the growth of both fibroblasts and osteoblasts, when using an autologous fibrin glue in mandibular defects of humans. ${ }^{122}$ Segura-Castillo et al ${ }^{125}$ also noted a considerable elimination of bone graft resorption in the reconstruction of alveolar clefts when using fibrin glue. This phenomenon allowed for the formation of a bridge between the healthy segments of the maxilla and the graft, which in turn improved integration of the graft through facilitating cellular migration. ${ }^{125} \mathrm{Huh}$ et al used autologous platelet-enriched fibrin glue (in which fibrinogen and thrombin were concentrated from plateletrich plasma instead of the whole plasma) to improve bone regeneration capacity of the autogenous particulate bone when repairing the mandible defects in mongrel dogs. ${ }^{126}$ The same authors, in their next studies, showed that the addition of platelet-enriched fibrin glue to autogenous bone grafts also effectively enhanced the vertical alveolar ridge ${ }^{127}$ and maxillary sinus floor augmentation in dogs. ${ }^{128}$ Despite these positive effects on the healing process, there are few reports on the negative effect of the combination of fibrin with an autologous bone graft on bone repair. Gerngross et al noted a negative impact on bone remodeling in the cortical tibia of a sheep model upon the addition of a fibrin sealant on autologous cancellous bone grafts. ${ }^{20}$ Lappalainen et $\mathrm{al}^{21}$ also observed a similar result upon the association of a fibrin glue with autologous particulate bone in rabbit critical-sized calvarial defects. The negative effect was explained by the potential role of fibrin in limiting the ingrowth of vessels into the grafted bone or its role as a void filler which prevents the formation of the natural fibrin. ${ }^{21}$

Due to the limitations related to the use of autologous bone graft, some authors have focused on combining autologous bone grafts with osteoconductive bioceramics to, at least partially, overcome such problems. Hallman et al ${ }^{129,130}$ augmented the maxillary sinus floor of 20 patients with a mixture of bovine hydroxyapatite $(\mathrm{BH})$, autogenous bone particles, and fibrin glue. Histological evaluation 6 months and 3 years after the procedure showed bone formation on the surface of the grafted materials. After 6 months, the bone that was formed around the $\mathrm{BH}$ particles was immature woven bone, while observations after 3 years showed that the mature lamellar bone replaced the woven bone. ${ }^{129,130}$ Such grafts were also used to enable the insertion of Ti implants into the maxillary sinus floor of 20 patients with acceptable long-term results. ${ }^{131}$

On the other hand, the use of pure bioceramics in combination with fibrin glue has shown promising results in terms of handling characteristics of materials and adherence to the surrounding tissues. ${ }^{132}$ Woo et al reported injectability of calcium sulfate ceramic powders was enhanced when combined with fibrin glue. ${ }^{133}$ Similarly, Lopez-Heredia et al reported that the fibrin glue improved porosity, pore size, pore size distribution, and interconnectivity of the CPCs paste. These factors can be easily controlled by the ratio of fibrin glue to ceramic powders. ${ }^{30}$ On the other hand, adding sufficient amounts of long setting fibrin, obtained using low thrombin concentrations, changed the fracture behavior of the ceramics, so that composite could maintain its shape even after reaching the maximal load and failure. ${ }^{30}$

It is important to note that in bone tissue engineering, the total mechanical properties of the implants including stiffness, toughness, and strength should be as close as possible to that of the normal bone. Ono et al implanted apatite-wollastonite containing glass ceramic (A-W.GC) granules with/without a fibrin sealant in the femoral defects of rabbits and after 24 weeks reported a better match of the mechanical properties of the implant site to those of normal 
cancellous bone in the fibrin-containing group. In addition, they noted that as the volume ratio of fibrin to granules increased from $1: 1$ to $4: 1$, the mechanical properties of the implant site came closer to those of normal cancellous bone. ${ }^{29}$ Dong et al also showed that the fibrin glue effectively enhances the mechanical properties of CPC nanoparticles ${ }^{134}$ and microparticles ${ }^{135}$ compared to the $\mathrm{CPC} /$ water group both in vitro and after implantation in the femurs of rabbits.

However, the benefit of fibrin glue on the bone repair capacity of bioceramics is a matter of controversy. Some reports show that fibrin glue not only enhances the physical and mechanical properties of the ceramics but also improves their biological performance, while others claim that fibrin glue jeopardizes the regeneration of bone tissue. Moreover, some findings indicate that fibrin glue enhances handling characteristics of ceramics but does not promote or inhibit the process of osteogenesis. Several reports highlighted the benefit of fibrin glue on the repair capacity of bioceramics. Kania et al found that adding commercial or single-donor fibrin to coral granules stimulates the early rate of bone regeneration. ${ }^{136}$ Woo et al observed enhanced proliferation and differentiation of the osteoblasts upon the addition of a fibrin sealant to calcium sulfate cements. ${ }^{133}$ Ono et $\mathrm{al}^{28}$ reported that the addition of fibrin glue to the A-W.GC granules improved both early vascularization and bone formation of the mixtures after implanting them into the defects located in the proximal metaphysis of the rat tibia. Higher ratios of fibrin to ceramics, possibly by increasing the bone formation space, further enhances the bone regeneration. ${ }^{28}$ Similarly, Dong et al added fibrin gels to CPC nanoparticles and implanted the mixture into the femoral defects of rabbits and observed greater regenerated bone in the fibrin/ CPC group compared to CPC alone. ${ }^{134}$ The CPC/fibrin glue system can also act as a carrier for BMPs that remarkably enhances the bone regeneration potential of the composite. ${ }^{137}$ Guehennec et al noted a potential osteoinductive role for a fibrin sealant when added to BCP ceramics, while pure BCP showed an osteoconductive phenomenon. ${ }^{138}$ Furthermore, deep bone colonization appeared to be slower for the fibrin/ ceramic group compared to the ceramic alone group; probably because fibrin in the composite group filled the space between the granules. ${ }^{138}$ The same group also showed that following sinus lift augmentation in the sheep models, the $\mathrm{BCP} /$ fibrin grafting was effective as equal or even superior to autologous bone grafting. ${ }^{139}$ They also successfully used this composite for the treatment of bone defects that resulted from tumor resection or curettage in 51 patients. ${ }^{140}$ Recently, van Esterik et al achieved success in improving osteogenic and vasculogenic differentiation potential of $\mathrm{BCP} /$ fibrin scaffold by modifying the composition of BCP from a $\mathrm{HA} / \beta$ tricalcium phosphate (HA/ $\beta$-TCP) ratio of 60/40 (BCP 60/40) to $\mathrm{HA} / \beta$-TCP ratio of $20 / 80$ (BCP 20/80). ${ }^{141}$

As mentioned earlier, some researchers noted a negative impact of fibrin on bone repair. For example, Carmagnola et $\mathrm{al}^{142}$ noted that adding fibrin to Bio-Oss particles resulted in 4 times less tissue contact between bone and biomaterials in mandibular defects of dogs. Besides, in contrast to Bio-Oss alone group, no soft connective tissue replacement with newly formed bone was observed in Bio-Oss/fibrin treated defects. ${ }^{142}$ A fibrin sealant was also reported to inhibit bone induction in the abdominal muscles of rats when used in combination with demineralized bone particles. The inhibited bone formation was perhaps due to the immunological response to xenogeneic proteins (fibrinogen and thrombin were from humans and aprotinin was of bovine origin). ${ }^{143}$ Similarly, Bösch et al found that while heterologous fibrin impaired the bone healing process, due to a local immune response, homologous fibrin accelerated the growth of capillary vessels and connective tissue cells, which resulted in rapid new bone formation. ${ }^{144}$ Other researchers argued that the addition of a fibrin sealant to coral granules limited the infiltration of osteoprogenitor cells into the implantation area. ${ }^{145}$ This was further confirmed by an observed delay in bone formation in femoral defects of rats implanted with fibrin-containing PLGA/calcium phosphate scaffolds. The authors stated that high concentrations of fibrinogen $(35-55 \mathrm{mg} / \mathrm{mL})$ used for their experiments probably impeded cell invasion into the defects and caused delayed bone healing. ${ }^{33}$

\section{Fibrin glue as an injectable delivery system in bone tissue engineering}

Investigations have shown that the incorporation of osteogenic cells and/or biological factors into a fibrin matrix promotes bone healing. On the other hand, it has been documented that when osteogenic cells were mixed with fibrin glue, more bone formation occurred compared to a combination of cells with liquids, such as medium liquid ${ }^{146}$ and phosphate-buffered saline. ${ }^{38}$ Hence, here it is stated that both scaffolds and cells have critical roles in bone regeneration. Table 4 presents some of these applications of fibrin in bone tissue engineering which are explained in more detail below.

\section{Cell delivery}

Seebach et al $^{147}$ provided evidence that fibrin supports the early action of implanted BMSCs, such as host cell recruitment, modulation of the early inflammatory reaction, acceleration of new vessel formation and bone regeneration in the femoral defects of rats. Therefore, the authors suggested 
Table 4 Delivery of cells and/or biomolecules to a bone defect site by fibrin

\begin{tabular}{|c|c|c|c|c|}
\hline Cell & Biomolecule & Adjacent biomaterial & Implantation site & References \\
\hline BMSCs & & & Femur of rat & 147 \\
\hline MSCs and ECFCs & & & & 200 \\
\hline $\begin{array}{l}\text { BMSCS or periosteal cells } \\
\text { or alveolar bone cells }\end{array}$ & BMP-2 & & Subcutaneous tissue of mouse & 149 \\
\hline \multirow[t]{8}{*}{ BMSCs } & & Particulate mineralized bone & Tibia of rabbit & $|5|$ \\
\hline & BMP-2 & & Femur of rats & 157 \\
\hline & Non glycosylated form & & Calvarium of rat & 158 \\
\hline & of BMPs & & & \\
\hline & BMP-2 & Heparin conjugated fibrin system & Muscle of rat & 163 \\
\hline & Substance $\mathrm{P}$ (fast release) & Heparin conjugated fibrin system & Calvarium of mouse & 170 \\
\hline & and BMP (slow release) & & & \\
\hline & BMP-2 & $\beta-\mathrm{TCP}$ & Calvarium of rats & 159 \\
\hline AMSCs & BMP-2 and PDGF & & Calvarium of mouse & 177 \\
\hline Osteoblasts & bFGF & & Subcutaneous tissue of rat & $4 I$ \\
\hline BMSCs & Vancomycin & Alginate beads & Tibia of rabbit & 184 \\
\hline Stromal vascular fraction & BMP-2 & $\begin{array}{l}\text { Silicated calcium- } \\
\text { phosphate granules }\end{array}$ & Subcutaneous tissue of mouse & 154 \\
\hline
\end{tabular}

Abbreviations: BMP-2, bone morphogenetic protein-2; $\beta$-TCP, $\beta$-tricalcium phosphate; PDGF, platelet-derived growth factor; substance $\mathrm{P}$, a small peptide that effectively recruits MSCs to damaged tissues; BMSC, bone marrow-derived stromal cell; MSC, mesenchymal stem cell; ECFC, endothelial colony-forming cell; AMSC, adipose mesenchymal stem cell; bFGF, basic fibroblast growth factor.

that a fibrin hydrogel can serve as an attractive carrier for MSC-based tissue engineering approaches. ${ }^{147}$

Kim et al used fibrin-containing osteoblasts (obtained from the bone marrow of the iliac crest) to regenerate radial shaft defects of rabbits and noted that results were comparable to an autologous iliac bone graft. ${ }^{148}$ In addition to BMSCs, researchers mixed several other cell types with fibrin to accelerate bone repair. Park et al proposed skin-derived mesenchymal stem cells (SMSCs) as an alternative to BMSCs after confirming the bone formation capacity of SMSCs both in vitro and in a mouse subcutaneous model. In these experiments, cell-embedded fibrin gels were injected into a demineralized bone matrix (DBM) scaffold. ${ }^{39}$ Moreover, Zhu et al showed that periosteal cells have more bone formation potential compared to BMSCs or alveolar bone cells when mixed with single-donor fibrin glues and were injected into the subcutaneous space on the dorsum of nude mice. ${ }^{149}$ However, McDuffee et al reported that BMSCs are more osteogenic than muscle-derived stem cells (MDSCs) when implanted intramuscularly into mice. ${ }^{38}$ Despite this promising outcome, bone tissue engineering can always benefit from a more efficient cell/fibrin construct. For instance, Zhao et al demonstrated that the incorporation of $\beta$-tricalcium phosphate nanoparticles in a fibrin glue significantly increased both proliferation and ALP expression of entrapped MSCs. ${ }^{150}$ Therefore, fibrin composites, such as particulate allogenic bone/fibrin ${ }^{151}$ and gelatin/nano $\mathrm{HA} /$ fibrin, ${ }^{36}$ are preferred for cell delivery purposes over fibrin alone. The co-delivery of growth factors and cells is another attractive approach to enhance the efficiency of a fibrin/cell mixture. Ito et al ${ }^{152}$ filled fibrin, fibrin/autologous BMSCs, and fibrin/BMSCs/autologous platelet-rich plasma around metallic implants in a mandible defect of dogs. Histological and histomorphometric analyses after 4 and 8 weeks showed more bone-implant contact in the fibrin/ cell group compared to fibrin alone, which was enhanced even more significantly when the fibrin/cells/platelet gel was used altogether. ${ }^{152}$ Liu et al found that the delivery of MSCs and rhBMPs using fibrin glue was more effective in posterolateral spinal fusion compared to the delivery of single MSCs or rhBMPs. ${ }^{153}$ Similarly, Mehrkens et al found that addition of $250 \mathrm{ng}$ of rhBMP-2 inside the fibrin gel in conjunction with freshly isolated stromal vascular fractions (SVFs) of human adipose tissue induced ectopic bone tissue formation in mice, ${ }^{154}$ while in the absence of incorporated BMP-2, the construct did not display any evidence of bone tissue formation. ${ }^{154,155}$ However, recently, the authors noted that at orthotopic sites, exogenous BMP was not necessary and SVF could form bone tissue and vessel structures in a critically sized rat femoral defect. After that, autologous SVF cells were used to successfully treat low-energy proximal humeral fractures in 8 patients. ${ }^{156}$

\section{BMP delivery}

BMPs, which belong to the transforming growth factor (TGF) superfamily, are the most potent osteoinductive proteins. BMPs induced MSCs to migrate to bone-forming sites, differentiate into an osteoblast lineage, and regenerate bone. ${ }^{157}$ Local pharmacokinetics are very important for the therapeutic efficacy of BMPs. For example, when 
BMP-2 in saline is placed at the site of a bone defect, it is quickly cleared from that site, resulting in minimal bone formation and healing. ${ }^{158}$ Besides this minimal effect, the rapid release of BMP-2 can cause adverse effects and will require more frequent administration which is costly. ${ }^{157}$ Therefore, it is necessary to develop a delivery system that can release BMPs locally for a sufficient time period and concentration. Among several different BMP carriers, a fibrin matrix is considered as an excellent carrier. Schützenberger et $\mathrm{al}^{157}$ added BMP-2 to fibrinogen and then mixed it with thrombin. Their in vivo study in a rat femoral defect showed that although compared to a commercially available absorbable collagen sponge-BMP-2 system, a 7-fold lower dose of BMP-2 used in fibrin gels, the fibrin-BMP-2 system would result in equal or superior bone formation versus a collagen/ BMP-2 system. ${ }^{157}$ As in the case of cell delivery, the addition of osteoconductive agents such as $\beta$-tricalcium phosphate to a fibrin carrier intensifies the efficacy of a delivery system. ${ }^{159}$ Fibrin glue was also used to encapsulate collagen sponges loaded with BMPs and block bone formation in undesired areas by limiting BMP diffusion. ${ }^{160}$ However, due to the relatively small size of BMPs compared to the pores of fibrin and their low affinity to interact with fibrin, BMPs were released quickly from the fibrin glue. ${ }^{158}$ Hence, efforts have been made to enhance the delivery capacity from a fibrin glue. Schmoekel et al found that a less soluble form of BMPs, a non-glycosylated form (nglBMP-2), resulted in a more gradual release of growth factors in a Tris-buffered saline and therefore more bone healing compared to conventional soluble BMPs. ${ }^{158}$ The utility of ng1BMP-2 was also confirmed in a series of prospective veterinary clinical trials. ${ }^{158,161}$ The same group in another strategy designed a tripartite fusion protein, referred to as TG-pl-BMP-2 with TG denoting a transglutaminase-sensitive binding domain and $\mathrm{pl}$ the plasmin-sensitive linking domain. TG-pl-BMP-2 can be covalently incorporated into a fibrin matrix under the influence of the blood transglutaminase factor XIIIa, while a plasmin substrate provides a cleavage site for the local release of the attached growth factor under the influence of cell-activated plasmin. The authors observed that this system noticeably enhanced the bone healing process in the rat calvaria model compared to wildtype BMP-2 and also pancarpal fusion in dogs compared to a cancellous bone autograft. ${ }^{162}$

In another approach, Yang et al, conjugated heparin to fibrin and bound BMPs to heparin via electrostatic interactions between negatively charged sulfate groups of heparin and positively charged amino acid residues of the BMP-2 proteins. ${ }^{163,164}$ In addition to the BMP-2 interaction with heparin in heparin-conjugated fibrin (HCF) systems, the release of BMP-2 could also be affected by the in vivo slower degradation of HCF compared to regular fibrin. ${ }^{164}$ The efficiency of the HCF system for bone regeneration has been assayed in different animal studies including the hind limb muscle of rats, ${ }^{163}$ calvarial defects in mice, ${ }^{165}$ and spinal fusion in rabbits. ${ }^{166}$ Hong et $\mathrm{al}^{166}$ found that a very low dose $(37.5 \mu \mathrm{g})$ of commercial BMP-2 applied in an $\mathrm{HCF}$ carrier promoted bone formation comparable to that of an autograft in a rabbit spinal fusion model. However, the authors emphasized that human host tissue is much less responsive than that of rodents; hence, before clinical utilization, large animal models should be used to test an HCF system with various doses of BMP-2. ${ }^{166}$ This gradual release of BMP-2 can also reduce the potential side effects of excessive fatty marrow formation. ${ }^{167}$ However, results from other studies of the same group demonstrated that heparinconjugated PLGA nanospheres provide more control on protein release in vitro and bone formation in vivo compared to HCF systems. ${ }^{163,168}$ The BMP-2 release rate was further slowed down by using a delivery system of apatite-coated PLGA/HA particulates as a carrier for the controlled release of BMP-2 which was suspended in the fibrin gel. ${ }^{168,169}$ The adsorption and desorption of BMP-2 on HA occur through the physicochemical and electrostatic interactions between amino groups of proteins and a negatively charged site of HA crystals. Moreover, BMP-2 is released from a fibrin gel by a simple diffusion mechanism, which causes a short-term release of BMP-2. Hence, the long-term release of BMP-2 from apatite-coated PLGA/HA particulates suspended in a fibrin gel may be attributed to the combination of the two release mechanisms. ${ }^{169}$ Figure 7 represents the bone formation ability of an apatite-coated PLGA/HA particulate/fibrin system in a critical-sized calvarial defect in rats. ${ }^{169}$ The HCF system can be also employed to release multiple factors at different rates. In this scenario, the authors co-delivered a substance P (SP), a small peptide that is quickly released from the HCF gel and effectively recruits MSCs to damaged tissues and BMPs to further enhance the bone regeneration capacity of the HCF systems. The HCF gels with SP and/or BMP-2 were implanted into mouse calvarial defects for 8 weeks, and the results showed that the efficacy of bone regeneration was significantly higher in the SP/BMP-2 dual delivery group. ${ }^{170}$

As mentioned in the previous sections, the use of genetically engineered cells and viruses is another approach to deliver BMPs to a desired site. Usas et al used transduced 
A

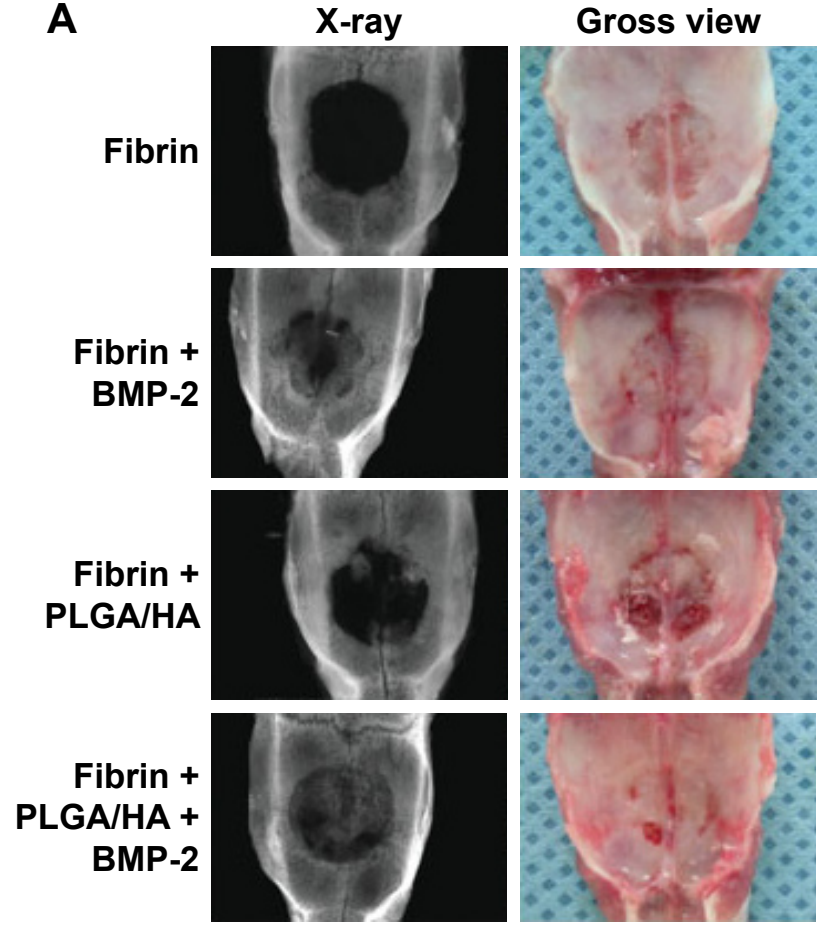

B

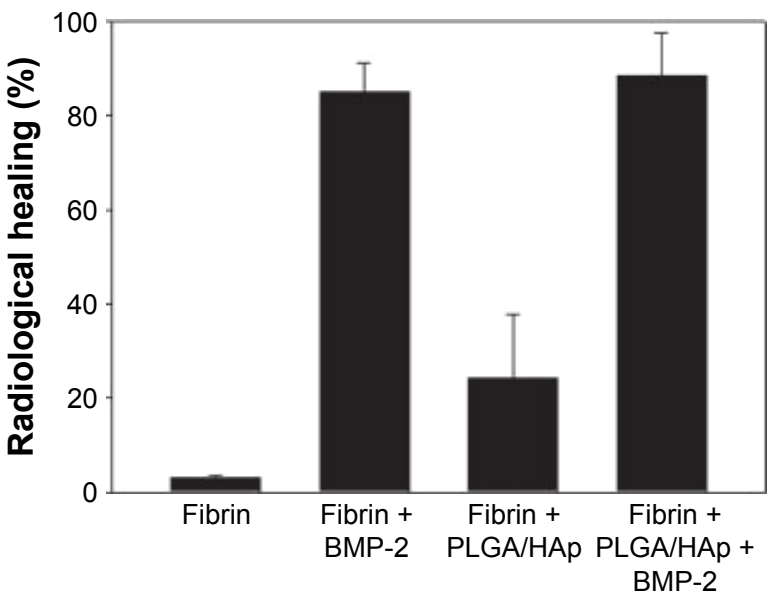

Figure 7 (A) Gross examination and soft X-ray examination of the fibrin gel group, fibrin gel apatite-coated PLGA/HA particulate group, BMP-2-loaded fibrin gel group, and BMP-2-loaded apatite-coated PLGA/HA particulates suspended in a fibrin gel group at 8 weeks after implantation into critical-sized calvarial defects of rats. (B) Radiological defect healing at 8 weeks. Reproduced from Kim SS, Gwak SJ, Kim BS. Orthotopic bone formation by implantation of apatite-coated poly (lactide-co-glycolide)/hydroxyapatite composite particulates and bone morphogenetic protein-2.J Biomed Mater Res A. 2008;87(I):245-253. ${ }^{169}$

Abbreviations: PLGA, poly(lactic-co-glycolic acid); HA, hydroxyapatite; BMP-2, bone morphogenetic protein 2; HAp, hydroxylapatite particulates.

MDSC secreting BMP-4 in hydrogels, such as fibrin, to promote bone regeneration in the calvarium of mice. ${ }^{171}$ Sheyn et al showed that genetically modified porcine ASCs which overexpress rhBMP6 can induce vertebral defect regeneration in rodents ${ }^{172}$ and in a clinically relevant, large animal pig model. ${ }^{173}$ Immunohistochemical analyses also indicated that ASCs not only secrete BMPs but also differentiate into bone-forming cells in response to osteogenic induction and are actively involved in tissue regeneration itself. ${ }^{172}$ However, there is some argument concerning the superior osteogenic potential of genetically modified BMSCs compared to that of modified ASCs both in vitro and in vivo. ${ }^{174}$ In another study, Schek et al ${ }^{146}$ mixed BMP-7 expressing adenovirus with collagen, fibrin, or cell culture medium and implanted them intramuscularly into nude mice. After 4 weeks, radiological and histological analyses showed a superior ability of fibrin glue to deliver the virus. Interestingly, in vitro culturing of mouse fibroblasts on a fibrin-contained virus showed that fibrin gel concentrations considerably affected viral infections of cells since lower fibrin concentrations resulted in a higher transduction levels of cells. The authors explained that the difference in fibrin structures led to differences in the diffusion rate of a virus which directly affected the infection of cells. ${ }^{146}$

\section{Biomolecules other than BMP delivery}

Many studies used fibrin for the delivery of other biomolecules. bFGF is a $16 \mathrm{kDa}$ polypeptide that has osteogenic properties in addition to well-known angiogenic properties. ${ }^{175}$ Jeon et $\mathrm{al}^{176}$ demonstrated that by increasing thrombin or fibrinogen concentrations, a fibrin gel with a dense structure and also decreased degradation rate can be created to slow down bFGF diffusion. On the other hand, the incorporation of heparin to fibrin significantly retarded the release of bFGF from the hydrogel because heparin interacts with both bFGF and fibrin, and this specific interaction resulted in a slow release of growth factors. ${ }^{176}$ In their next study, the researchers subcutaneously implanted fibrin-contained bFGF and/or osteoblasts in rats and found that compared to the delivery of osteoblasts alone, co-delivery of bFGF and osteoblasts resulted in two and nine times more bone formation and calcium content, respectively. The authors attributed these effects to enhanced osteogenic gene expression of the transplanted cells and neovascularization of the transplants. ${ }^{41}$

Zhang et al showed significantly improved revascularization as well as quality and speed of bone healing upon the delivery of VEGF to femoral defects, using fibrin-suspended PLGA microspheres. ${ }^{44}$ PDGF is a growth factor secreted 
by activated platelets which stimulates the repair mechanisms in wounded tissues such as bone. It has been shown that the addition of PDGF to cell culture medium of fibrin gels containing aggregated multicellular spheroid adipose mesenchymal stem cells significantly improves both vascularization and mineralization by cells. Vila et al also used fibrin glue for the controlled delivery of an engineered form of PDGF and BMP-2 to enhance bone and vasculature formation in mouse calvarial defects. ${ }^{177}$ The same approach is involved in the delivery of parathyroid hormone (PTH1-34) which increases bone turnover via a direct and indirect effect on osteoblasts and osteoclasts. In a study by Arrighi et al, ${ }^{178}$ an inactive prodrug TG-pl-PTH1-34 was immobilized to fibrin as in the case of TG-pl-BMP-2 (see section BMP delivery). After plasmin-induced cleavage, the released active PTH1-34 promoted bone regeneration at the desired site. The bone-forming capability of the PTH1-fibrin system was demonstrated in the femoral and humerus defects in sheep. ${ }^{178}$ Zoledronate (ZOL) is a bisphosphonate used to treat osteoporosis by inactivating osteoclastic functions and promoting osteoclastic apoptosis. Jing et al encapsulated ZOL plus BMP-2 in a fibrin sealant and used the obtained system to repair the femoral necks of osteoporotic rabbits. ${ }^{179}$ Fibrin scaffolds were also used for the delivery of heparan sulfate (HS), which is another bioactive factor enhancing bone repair. The uniform distribution of HS in the fibrin scaffolds was achieved by adjusting the concentration of thrombin, which demonstrates significant improvements in bone formation when injected into rat calvarial defects. ${ }^{180}$

Fibrin glue has also been used for efficient and adequate delivery of antibiotics to the desired location. Tofuku et al reported that the use of an antibiotic-impregnated fibrin sealant (AFS) significantly reduced the rates of deep surgical site infections (SSIs) in patients who underwent implantation of orthopedic hardware surgery; 11 of the 188 patients acquired a deep SSI in the group treated without AFS while none of the 196 patients acquired a deep SSI in the other group. ${ }^{181}$

Another research area is the treatment of bone defects that suffer from infection. Co-delivery of antibiotic and osteogenic cells via a fibrin scaffold may be an ideal option. To this end, Hou et al ${ }^{182}$ embedded vancomycin alginate beads in a fibrin gel to supply sustained antibiotics at the graft site, while BMSCs seeded in the gel promoted bone regeneration. In vitro results showed that cell morphology did not change with exposure to the antibiotic beads but that cell proliferation and differentiation were enhanced in fibrin scaffolds containing antibiotic beads. The more porous fibrin structure resulting from the inclusion of the beads and presence of alginate were suggested as possible reasons for cell function improvement. ${ }^{182}$ In their future in vivo study, they showed that inclusion of vancomycin alginate beads/ fibrin in a DBM exhibited no negative impact on the process of osteogenesis and wound healing in the femoral defects of goats. ${ }^{183}$ In addition, they successfully treated chronic osteomyelitis of rabbit tibia by a vancomycin alginate bead/ BMSCs/fibrin gel delivery system. ${ }^{184}$

\section{Application of nanotechnology in fibrin-based bone tissue engineering}

In recent years, nanotechnology has become more prevalent and has found widespread use in the field of bone tissue engineering, especially in the fabrication of nanoparticles and nanofibrous scaffolds which mimic the structural hierarchy of native ECM. The diameter of fibrin fiber ranges between tens and a few hundreds of nanometers; therefore, all fibrin discussed in the previous sections are natural nanostructures. However, researchers have tried to develop methods by which they can precisely control the nano- and microstructure of fabricated fibrin scaffolds. Linnes et al ${ }^{185}$ developed a method by which fibrin scaffolds of defined pore size, porosity, and microstructure can be fabricated. Such procedures involved pouring a fibrinogen and thrombin solution around an interconnected template made of PMMA beads. After polymerization of fibrin, the PMMA beads were dissolved in acetone through several rinses using acetone and the scaffolds were resolvated in $70 \%$ ethanol overnight. ${ }^{185}$ Next, the authors incorporated calcium phosphate nanoparticles into the matrices and observed that in vitro culturing of osteoblast-like cells on modified scaffolds resulted in significantly higher ALP activity as well as osteoblast marker gene expression compared to fibrin scaffolds, while higher cell proliferation was detected on fibrin alone scaffolds. An in vivo study was performed by the implantation of disc-shaped scaffolds in cranial defects of mice, and the results demonstrated the promotion of bone formation in defects treated with fibrin/calcium phosphate scaffolds. In addition, scaffolds could serve as a delivery system for BMP-2 to further improve bone regeneration. ${ }^{186}$ In their next study, the authors covalently immobilized ALP on the fibrin scaffolds using 1-ethyl-3-(3-dimethylaminopropyl) carbodiimide hydrochloride. In vitro and in vivo results showed a superior bone-forming ability of immobilized ALP scaffolds compared to the fibrin alone group. However, the outcome was not robust, and the authors suggested that additional factors and/or procedures are required to achieve better results in vivo. ${ }^{187}$ 
Electrospinning is a unique technique that uses electrostatic forces and produces polymer fibers with diameters ranging from a few nanometers to a few microns. For the first time, Perumcherry et a $1^{188}$ uniformly electrospun fibrin into nanofibers. Briefly, fibrinogen and thrombin solutions were separately mixed in a PVA solution. PVA was used as a carrier of fibrin to aid in electrospining. These two solutions were taken separately in two syringes and connected to a delivery device having a common needle at the end of the syringes. By applying a high voltage, the flow rate of the solutions was adjusted in such a way that the fibrin formation took place just before the formation of a fiber jet. SEM images revealed the formation of bead-free fibers with a dimension ranging from 50 to $500 \mathrm{~nm} .{ }^{188} \mathrm{Next}$, the authors fabricated a fibrin-based multiscale hybrid scaffold by sequential electrospinning of fibrin and PCL (Figure 8) or simultaneous electrospinning of fibrin and PLGA ${ }^{189}$ to combine the benefits of biological properties of the fibrin and the excellent mechanical properties of the synthetic polymers.

Beside nanofibrous fibrin scaffolds, fibrin nanotubes and fibrin nanoparticles (FNPs) can be prepared by a water-inoil emulsification-diffusion route. These constructs showed excellent stability against aggregation and high temperatures and also had the ability to deliver drug and growth factors in a controlled manner. ${ }^{190}$ These nano-fibrin scaffolds were also used to enhance angiogenesis in chitin/poly (butylene succinate)/bioactive glass ${ }^{191}$ and chitin/calcium sulfate gels. ${ }^{192}$ Vedakumari et al ${ }^{193}$ developed a wet precipitation method for synthesizing FNPs. In this technique, first, a crude form of fibrin was isolated from bovine blood by stirring the blood with a glass rod. Next, the obtained fibrin was washed, treated by $0.5 \mathrm{M}$ sodium acetate, and $30 \%$ hydrogen peroxide and grounded. Later, fibrin was dissolved in $\mathrm{NaOH}$ $(1 \mathrm{~N})$, and then $\mathrm{HCl}(1 \mathrm{~N})$ was added dropwise under vigorous

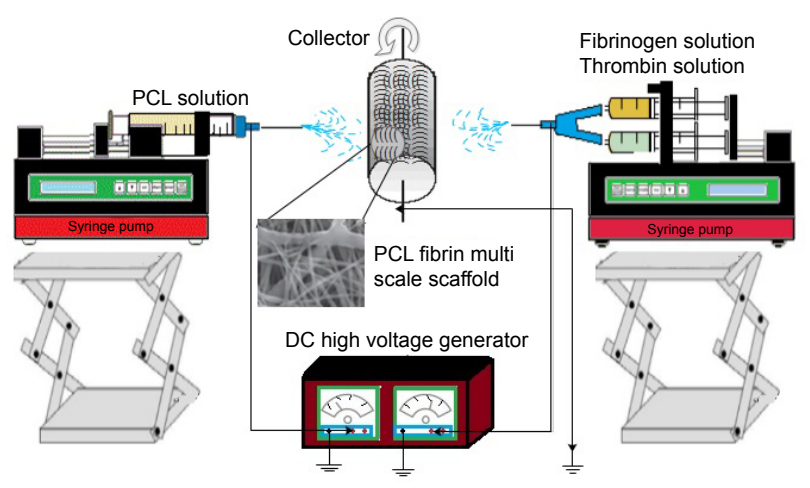

Figure 8 Schematic representation of the electrospinning of PCL fibrin multiscale nanoscaffolds. The arrows indicate steps that are repeated sequentially to obtain a composite scaffold.

Abbreviations: DC, direct current; PCL, poly caprolactone. stirring which eventually led to the formation of FNPs at $\mathrm{pH}$ 5.5. Biocompatibility of the FNPs was demonstrated by in vitro and in vivo analyses. ${ }^{193}$ The authors, in their next study, prepared magnetic FNPs (MAG-FNPs). To this, they incinerated red blood cells of defibrinated blood and dissolved the residue in $5 \mathrm{~N} \mathrm{HCl}$ to obtain an iron solution which was added dropwise to a fibrin/ $\mathrm{NaOH}$ solution as mentioned earlier. The MAG-FNPs were crystalline and spherical with sizes ranging from 12 to $15 \mathrm{~nm}$ which improved the ALP activity of Saos- 2 cells. Therefore, the authors concluded that MAG-FNPs could be widely used for magnetic field assisted bone tissue engineering applications. ${ }^{194}$ Nanocomposites of iron-fibrin nanohydroxyapatite (IF-nHAp) were another novel biomaterial developed by them. IF-nHAp was needle shaped with an average width of $\sim 30 \mathrm{~nm}$ and length of $80 \mathrm{~nm}$. When an MG-63 cell line was cultured in the presence of this composite, its osteogenic potential improved as noted by the upregulated expression of osteogenic genes and enhanced calcium deposition and mineralization. ${ }^{195}$

In this manner, as one can easily determine, the efficacy of fibrin was improved through its incorporation with nanoscaffolds and nanomaterials. It has been speculated that such nanomaterials improve the bioactivity of fibrin and availability of fibrin to interact with cells. It is important to mention in this context that nanomaterials have more surface area for interactions with fibrin, and since fibrin itself is a nanostructured protein, its bioactivity can be manipulated through nanostructures.

\section{Conclusion and future trends}

Fibrin is one of the most promising biopolymers used for bone tissue engineering applications, and therefore, the literature on the use of fibrin in this field is extensive and continues to evolve. Indeed, the combination of excellent biocompatibility, biodegradability, intrinsic bioactivity, and many other unique characteristics make fibrin an attractive biomaterial for bone tissue engineering. As mentioned in previous sections, commercial fibrin glues are expensive and are associated with the risk of disease transmission while single-donor fibrin glues suffer from batch-to-batch diversity. In the future, the development of fibrinogen and thrombin as recombinant proteins may solve these problems. Further studies have shown that fibrin alone is incapable of healing bone defects, and so, addition of other materials and/ or biomolecules is unavoidable. The combination of fibrin with osteoconductive ceramics that allows the incorporation of growth factors, drugs, and metallic ions may enable the fabrication of multifunctional scaffolds that stop bleeding by 
homeostasis features, deliver therapeutic agents depending on pathological situations, and promote bone tissue remodeling. Another issue that deserves further investigation related to fibrin involves its preparation from platelet-rich plasma. Although platelets are considered as a huge reservoir of growth factors, their specific role(s) in the repair of bone is poorly understood. Considering problems, like a very limited range of platelet concentrations in which they exhibit positive effects in bone healing ${ }^{14}$ and interspecies variation in the growth factors. ${ }^{196}$ Therefore, more work is needed to translate the possible beneficial features of platelets to clinical practice. Lastly, the combination of nanomaterials with fibrin has shown tremendous potential in order to maximize its interactions with cells due to the increased surface area of nanomaterials and their ability to manipulate its bioactivity.

\section{Acknowledgments}

Financial support from the Iranian Nanotechnology Initiative Council is gratefully acknowledged. Special thanks also to Dr Javad Saberi for his consultation.

\section{Disclosure}

The authors report no conflicts of interest in this work.

\section{References}

1. Clarke B. Normal bone anatomy and physiology. Clin J Am Soc Nephrol. 2008;3(Suppl 3):S131-S139.

2. Sahoo NG, Pan YZ, Li L, He CB. Nanocomposites for bone tissue regeneration. Nanomedicine. 2013;8(4):639-653.

3. Blokhuis T, Arts JC. Bioactive and osteoinductive bone graft substitutes: definitions, facts and myths. Injury. 2011;42:S26-S29.

4. Zimmermann G, Moghaddam A. Allograft bone matrix versus synthetic bone graft substitutes. Injury. 2011;42:S16-S21.

5. Giannoudis PV, Dinopoulos H, Tsiridis E. Bone substitutes: an update. Injury. 2005;36(3):S20-S27.

6. Hench LL. Biomaterials: a forecast for the future. Biomaterials. 1998; 19(16):1419-1423.

7. Navarro M, Michiardi A, Castano O, Planell J. Biomaterials in orthopaedics. J R Soc Interface. 2008;5(27):1137-1158.

8. O'Keefe RJ, Mao J. Bone tissue engineering and regeneration: from discovery to the clinic - an overview. Tissue Eng Part B Rev. 2011;17(6): 389-392.

9. Bose S, Roy M, Bandyopadhyay A. Recent advances in bone tissue engineering scaffolds. Trends Biotechnol. 2012;30(10):546-554.

10. Szpalski C, Wetterau M, Barr J, Warren SM. Bone tissue engineering: current strategies and techniques - part I: scaffolds. Tissue Eng Part B Rev. 2012;18(4):246-257.

11. Bongio M, van den Beucken JJ, Leeuwenburgh SC, Jansen JA. Development of bone substitute materials: from 'biocompatible' to 'instructive'. J Mater Chem. 2010;20(40):8747-8759.

12. Polo-Corrales L, Latorre-Esteves M, Ramirez-Vick JE. Scaffold design for bone regeneration. J Nanosci Nanotechnol. 2014;14(1):15.

13. Breen A, O'Brien T, Pandit A. Fibrin as a delivery system for therapeutic drugs and biomolecules. Tissue Eng Part B Rev. 2009;15(2): 201-214.
14. Shiu HT, Goss B, Lutton C, Crawford R, Xiao Y. Formation of blood clot on biomaterial implants influences bone healing. Tissue Eng Part $B$ Rev. 2014;20(6):697-712.

15. Janmey PA, Winer JP, Weisel JW. Fibrin gels and their clinical and bioengineering applications. $J R$ Soc Interface. 2009;6(30):1-10.

16. Dietrich M, Heselhaus J, Wozniak J, et al. Fibrin-based tissue engineering: comparison of different methods of autologous fibrinogen isolation. Tissue Eng Part C Methods. 2012;19(3):216-226.

17. Dickneite G, Metzner H, Pfeifer T, Kroez M, Witzke G. A comparison of fibrin sealants in relation to their in vitro and in vivo properties. Thromb Res. 2003;112(1):73-82.

18. Weinand C, Gupta R, Huang AY, et al. Comparison of hydrogels in the in vivo formation of tissue-engineered bone using mesenchymal stem cells and beta-tricalcium phosphate. Tissue Eng. 2007;13(4):757-765.

19. Abiraman S, Varma H, Umashankar P, John A. Fibrin glue as an osteoinductive protein in a mouse model. Biomaterials. 2002;23(14): 3023-3031.

20. Gerngross PDH, Burri C, Claes L. Experimental studies on the influence of fibrin adhesive, factor XIII, and calcitonin on the incorporation and remodeling of autologous bone grafts. Arch Orthop Traum Su. 1986; 106(1):23-31.

21. Lappalainen O-P, Korpi R, Haapea M, et al. Healing of rabbit calvarial critical-sized defects using autogenous bone grafts and fibrin glue. Childs Nerv Syst. 2014;31(4):581-587.

22. Lack W, Bosch P, Arbes H. Chronic osteomyelitis treated by cancellous homografts and fibrin adhesion. J Bone Joint Surg Br. 1987;69(2): 335-337.

23. Greco F, De Palma L, Specchia N, Lisai P. Experimental investigation into reparative osteogenesis with fibrin adhesive. Arch Orthop Traum Su. 1988;107(2):99-104.

24. Bösch P, Lintner F, Arbes H, Brand G. Experimental investigations of the effect of the fibrin adhesive on the Kiel heterologous bone graft. Arch Orthop Traum Su. 1980;96(3):177-185.

25. Spear RL, Srigengan B, Neelakantan S, Bosbach W, Brooks RA, Markaki AE. Physical and biological characterization of ferromagnetic fiber networks: effect of fibrin deposition on short-term in vitro responses of human osteoblasts. Tissue Eng Part A. 2014;21(3-4):463-474.

26. Van der Stok J, Koolen M, De Maat M, et al. Full regeneration of segmental bone defects using porous titanium implants loaded with BMP-2 containing fibrin gels. Eur Cell Mater. 2015;29:141-154.

27. Lv J, Xiu P, Tan J, Jia Z, Cai H, Liu Z. Enhanced angiogenesis and osteogenesis in critical bone defects by the controlled release of BMP-2 and VEGF: implantation of electron beam melting-fabricated porous Ti6Al4V scaffolds incorporating growth factor-doped fibrin glue. Biomed Mater. 2015;10(3):035013.

28. Ono K, Yamamuro T, Nakamura T, Kokubo T. Apatite-Wollastonite containing glass ceramic granule-fibrin mixture as a bone graft filler: Use with low granular density. J Biomed Mater Res. 1990;24(1): $11-20$.

29. Ono K, Yamamuro T, Nakamura T, Kokubo T. Mechanical properties of bone after implantation of apatite-wollastonite containing glass ceramic-fibrin mixture. J Biomed Mater Res. 1990;24(1): $47-63$.

30. Lopez-Heredia M, Pattipeilohy J, Hsu S, et al. Bulk physicochemical, interconnectivity, and mechanical properties of calcium phosphate cements-fibrin glue composites for bone substitute applications. J Biomed Mater Res A. 2013;101(2):478-490.

31. Kim BS, Kim JS, Lee J. Improvements of osteoblast adhesion, proliferation, and differentiation in vitro via fibrin network formation in collagen sponge scaffold. J Biomed Mater Res A. 2013;101(9):2661-2666.

32. Zhou $\mathrm{H}, \mathrm{Xu} \mathrm{HH}$. The fast release of stem cells from alginatefibrin microbeads in injectable scaffolds for bone tissue engineering. Biomaterials. 2011;32(30):7503-7513.

33. Karp JM, Sarraf F, Shoichet MS, Davies JE. Fibrin-filled scaffolds for bone-tissue engineering: an in vivo study. J Biomed Mater Res A. 2004; 71(1):162-171. 
34. Soumya S, Sreerekha P, Menon D, Nair SV, Chennazhi KP. Generation of a biomimetic 3D microporous nano-fibrous scaffold on titanium surfaces for better osteointegration of orthopedic implants. J Mater Chem. 2012;22(5):1904-1915.

35. Schantz J-T, Brandwood A, Hutmacher DW, Khor HL, Bittner K. Osteogenic differentiation of mesenchymal progenitor cells in computer designed fibrin-polymer-ceramic scaffolds manufactured by fused deposition modeling. J Mater Sci Mater Med. 2005;16(9):807-819.

36. Liu Y, Lu Y, Tian X, et al. Segmental bone regeneration using an rhBMP-2-loaded gelatin/nanohydroxyapatite/fibrin scaffold in a rabbit model. Biomaterials. 2009;30(31):6276-6285.

37. Kang S-W, Kim J-S, Park K-S, et al. Surface modification with fibrin/ hyaluronic acid hydrogel on solid-free form-based scaffolds followed by BMP-2 loading to enhance bone regeneration. Bone. 2011;48(2): 298-306.

38. McDuffee LA, Gonzalez BPE, Nino-Fong R, Aburto E. Evaluation of an in vivo heterotopic model of osteogenic differentiation of equine bone marrow and muscle mesenchymal stem cells in fibrin glue scaffold Cell Tissue Res. 2014;355(2):327-335.

39. Park B-W, Kang E-J, Byun J-H, et al. In vitro and in vivo osteogenesis of human mesenchymal stem cells derived from skin, bone marrow and dental follicle tissues. Differentiation. 2012;83(5):249-259.

40. Galler KM, Cavender AC, Koeklue U, Suggs LJ, Schmalz G, D'Souza RN. Bioengineering of dental stem cells in a PEGylated fibrin gel. Regen Med. 2011;6(2):191-200.

41. Park MS, Kim SS, Cho SW, Choi CY, Kim BS. Enhancement of the osteogenic efficacy of osteoblast transplantation by the sustained delivery of basic fibroblast growth factor. J Biomed Mater Res B Appl Biomater. 2006;79(2):353-359.

42. Kneser U, Stangenberg L, Ohnolz J, et al. Evaluation of processed bovine cancellous bone matrix seeded with syngenic osteoblasts in a critical size calvarial defect rat model. J Cell Mol Med. 2006;10(3):695-707.

43. Steffens L, Wenger A, Stark GB, Finkenzeller G. In vivo engineering of a human vasculature for bone tissue engineering applications. J Cell Mol Med. 2009;13(9b):3380-3386.

44. Zhang L, Zhang L, Lan X, et al. Improvement in angiogenesis and osteogenesis with modified cannulated screws combined with VEGF/ PLGA/fibrin glue in femoral neck fractures. JMater Sci Mater Med. 2014; 25(4):1165-1172.

45. Jaquiéry C, Schaeren S, Farhadi J, et al. In vitro osteogenic differentiation and in vivo bone-forming capacity of human isogenic jaw periosteal cells and bone marrow stromal cells. Ann Surg. 2005;242(6): 859-868.

46. Catelas I. Fibrin. In: Ducheyne, editor. Comprehensive Biomaterials. Vol 2. Oxford: Elsevier; 2011:303-328.

47. Weisel JW. Fibrinogen and fibrin. Adv Protein Chem. 2005;70: 247-299.

48. Brown AC, Barker TH. Fibrin-based biomaterials: modulation of macroscopic properties through rational design at the molecular level Acta Biomater. 2014;10(4):1502-1514.

49. Helgerson sl ST, DiOrio JP, Tawil B, Bittner K, Spaethe R. Fibrin. In: Encyclopedia of Biomaterials and Biomedical Engineering. Vol 2. CRC Press; 2007:1072-1079.

50. Davis HE, Miller SL, Case EM, Leach JK. Supplementation of fibrin gels with sodium chloride enhances physical properties and ensuing osteogenic response. Acta Biomater. 2011;7(2):691-699.

51. Nair C, Shah G, Dhall D. Effect of temperature, $\mathrm{pH}$ and ionic strength and composition on fibrin network structure and its development Thromb Res. 1986;42(6):809-816.

52. Okada M, Blombäck B, Chang M-D, Horowitz B. Fibronectin and fibrin gel structure. J Biol Chem. 1985;260(3):1811-1820.

53. Weisel JW. The mechanical properties of fibrin for basic scientists and clinicians. Biophys Chem. 2004;112(2):267-276.

54. Ateshian GA, Hung CT. Functional properties of native articular cartilage. In: Guilak F, Butler DL, Goldstein SA, Mooney DJ. Functional Tissue Engineering. New York: Springer; 2003:46-68.
55. Weisel J. Structure of fibrin: impact on clot stability. J Thromb Haemost. 2007;5(s1):116-124.

56. Kim OV, Litvinov RI, Weisel JW, Alber MS. Structural basis for the nonlinear mechanics of fibrin networks under compression. Biomaterials. 2014;35(25):6739-6749.

57. Kim OV, Liang X, Litvinov RI, Weisel JW, Alber MS, Purohit PK. Foam-like compression behavior of fibrin networks. Biomech Model Mechanobiol. 2016;15(1):213-228.

58. Kolev K, Machovich R. Molecular and cellular modulation of fibrinolysis. Thromb Haemost. 2003;89(4):610-621.

59. Chernysh I, Everbach C, Purohit P, Weisel J. Molecular mechanisms of the effect of ultrasound on the fibrinolysis of clots. J Thromb Haemost. 2015;13(4):601-609.

60. Bluteau G, Pilet P, Bourges X, et al. The modulation of gene expression in osteoblasts by thrombin coated on biphasic calcium phosphate ceramic. Biomaterials. 2006;27(15):2934-2943.

61. El-Hakim IE. The effect of fibrin stabilizing factor (F. XIII) on healing of bone defects in normal and uncontrolled diabetic rats. Int J Oral Maxillofac Surg. 1999;28(4):304-308.

62. Kim BS, Lee J. Enhanced bone healing by improved fibrin-clot formation via fibrinogen adsorption on biphasic calcium phosphate granules. Clin Oral Implants Res. 2014;26(10):1203-1210.

63. Santos S, Lamghari M, Almeida C, et al. Adsorbed fibrinogen leads to improved bone regeneration and correlates with differences in the systemic immune response. Acta Biomater. 2013;9(7):7209-7217.

64. Maciel J, Oliveira MI, Colton E, et al. Adsorbed fibrinogen enhances production of bone- and angiogenic-related factors by monocytes/ macrophages. Tissue Eng Part A. 2013;20(1-2):250-263.

65. Linsley C, Wu B, Tawil B. The effect of fibrinogen, collagen type I, and fibronectin on mesenchymal stem cell growth and differentiation into osteoblasts. Tissue Eng Part A. 2013;19(11-12):1416-1423.

66. Colley H, McArthur SL, Stolzing A, Scutt A. Culture on fibrin matrices maintains the colony-forming capacity and osteoblastic differentiation of mesenchymal stem cells. Biomed Mater. 2012;7(4):045015.

67. Bensaid W, Triffitt J, Blanchat C, Oudina K, Sedel L, Petite H. A biodegradable fibrin scaffold for mesenchymal stem cell transplantation. Biomaterials. 2003;24(14):2497-2502.

68. Catelas I, Sese N, Wu BM, Dunn JC, Helgerson S, Tawil B. Human mesenchymal stem cell proliferation and osteogenic differentiation in fibrin gels in vitro. Tissue Eng. 2006;12(8):2385-2396.

69. Burnouf T, Su CY, Radosevich M, Goubran H, El-Ekiaby M. Bloodderived biomaterials: fibrin sealant, platelet gel and platelet fibrin glue. ISBT Science Series. 2009;4(1):136-142.

70. Ho W, Tawil B, Dunn JC, Wu BM. The behavior of human mesenchymal stem cells in 3D fibrin clots: dependence on fibrinogen concentration and clot structure. Tissue Eng. 2006;12(6):1587-1595.

71. Hale BW, Goodrich LR, Frisbie DD, McIlwraith CW, Kisiday JD. Effect of scaffold dilution on migration of mesenchymal stem cells from fibrin hydrogels. Am J Vet Res. 2012;73(2):313-318.

72. Linsley CS, Wu BM, Tawil B. Mesenchymal stem cell growth on and mechanical properties of fibrin-based biomimetic bone scaffolds. J Biomed Mater Res A. 2016;114(12):2945-2953.

73. Kim B-S, Sung H-M, You H-K, Lee J. Effects of fibrinogen concentration on fibrin glue and bone powder scaffolds in bone regeneration. J Biosci Bioeng. 2014;118(4):469-475.

74. Oh J-H, Kim H-J, Kim T-I, Baek J-H, Ryoo H-M, Woo KM. The effects of the modulation of the fibronectin-binding capacity of fibrin by thrombin on osteoblast differentiation. Biomaterials. 2012;33(16): 4089-4099.

75. Oh J-H, Kim H-J, Kim T-I, Woo KM. Comparative evaluation of the biological properties of fibrin for bone regeneration. BMB Rep. 2014; 47(2):110-114.

76. Murphy KC, Hughbanks ML, Binder BY, Vissers CB, Leach JK Engineered fibrin gels for parallel stimulation of mesenchymal stem cell proangiogenic and osteogenic potential. Ann Biomed Eng. 2015;43(8): 1-12. 
77. Matsumoto T, Sasaki J-I, Alsberg E, Egusa H, Yatani H, Sohmura T. Three-dimensional cell and tissue patterning in a strained fibrin gel system. PLoS One. 2007;2(11):e1211.

78. Sasaki J-I, Matsumoto T, Egusa H, et al. In vitro engineering of transitional tissue by patterning and functional control of cells in fibrin gel. Soft Matter. 2010;6(8):1662-1667.

79. Sasaki JI, Matsumoto T, Imazato S. Oriented bone formation using biomimetic fibrin hydrogels with three-dimensional patterned bone matrices. J Biomed Mater Res A. 2015;103(2):622-627.

80. Bardsley K, Wimpenny I, Wechsler R, Shachaf Y, Yang Y, El Haj AJ. Defining a turnover index for the correlation of biomaterial degradation and cell based extracellular matrix synthesis using fluorescent tagging techniques. Acta Biomater. 2016;45:133-142.

81. Le Guehennec L, Goyenvalle E, Aguado E, Pilet P, Spaethe R, Daculsi G. Influence of calcium chloride and aprotinin in the in vivo biological performance of a composite combining biphasic calcium phosphate granules and fibrin sealant. J Mater Sci Mater Med. 2007;18(8): 1489-1495.

82. Smith JD, Chen A, Ernst LA, Waggoner AS, Campbell PG. Immobilization of aprotinin to fibrinogen as a novel method for controlling degradation of fibrin gels. Bioconjug Chem. 2007;18(3):695-701.

83. Lorentz KM, Kontos S, Frey P, Hubbell JA. Engineered aprotinin for improved stability of fibrin biomaterials. Biomaterials. 2011;32(2): 430-438.

84. Cholewinski E, Dietrich M, Flanagan TC, Schmitz-Rode T, Jockenhoevel S. Tranexamic acid - an alternative to aprotinin in fibrinbased cardiovascular tissue engineering. Tissue Eng Part A. 2009;15(11): 3645-3653.

85. Demol J, Eyckmans J, Roberts S, Luyten F, Van Oosterwyck H. Does tranexamic acid stabilised fibrin support the osteogenic differentiation of human periosteum derived cells. Eur Cell Mater. 2011;21:272-285.

86. Jegoux F, Goyenvalle E, D'arc MB, Aguado E, Daculsi G. In vivo biological performance of composites combining micro-macroporous biphasic calcium phosphate granules and fibrin sealant. Arch Orthop Traum Su. 2005;125(3):153-159.

87. Burnouf T, Goubran HA, Chen T-M, Ou K-L, El-Ekiaby M, Radosevic M. Blood-derived biomaterials and platelet growth factors in regenerative medicine. Blood Rev. 2013;27(2):77-89.

88. Radosevich M, Goubran H, Burnouf T. Fibrin sealant: scientific rationale, production methods, properties, and current clinical use. Vox Sang. 1997;72(3):133-143.

89. Aizawa P, Winge S, Karlsson G. Large-scale preparation of thrombin from human plasma. Thromb Res. 2008;122(4):560-567.

90. Silver FH, Wang M-C, Pins GD. Preparation and use of fibrin glue in surgery. Biomaterials. 1995;16(12):891-903.

91. Franco D, Franco T, Schettino AM, Tavares Filho JM, Vendramin FS. Protocol for obtaining platelet-rich plasma (PRP), platelet-poor plasma (PPP), and thrombin for autologous use. Aesthetic Plast Surg. 2012;36(5): 1254-1259

92. Tabélé C. Organic glues or fibrin glues from pooled plasma: efficacy, safety and potential as scaffold delivery systems. J Pharm Pharm Sci. 2012;15(1):124-140.

93. Ahmed TA, Dare EV, Hincke M. Fibrin: a versatile scaffold for tissue engineering applications. Tissue Eng Part B Rev. 2008;14(2):199-215.

94. Soffer E, Ouhayoun JP, Anagnostou F. Fibrin sealants and platelet preparations in bone and periodontal healing. Oral Surg Oral Med Oral Pathol Oral Radiol Endod. 2003;95(5):521-528.

95. Civinini R, Macera A, Nistri L, Redl B, Innocenti M. The use of autologous blood-derived growth factors in bone regeneration. Clin Cases Miner Bone Metab. 2011;8(1):25-33.

96. Xuan F, Lee C-U, Son J-S, Jeong S-M, Choi B-H. A comparative study of the regenerative effect of sinus bone grafting with plateletrich fibrin-mixed Bio-Oss ${ }^{\circledR}$ and commercial fibrin-mixed Bio-Oss ${ }^{\circledR}$ : an experimental study. J Craniomaxillofac Surg. 2014;42(4):e47-e50.

97. Zangi L, Rivkin R, Kassis I, Levdansky L, Marx G, Gorodetsky R. High-yield isolation, expansion, and differentiation of rat bone marrowderived mesenchymal stem cells with fibrin microbeads. Tissue Eng. 2006;12(8):2343-2354.
98. Gurevich O, Vexler A, Marx G, et al. Fibrin microbeads for isolating and growing bone marrow-derived progenitor cells capable of forming bone tissue. Tissue Eng. 2002;8(4):661-672.

99. Gorodetsky R, Clark RA, An J, et al. Fibrin microbeads (FMB) as biodegradable carriers for culturing cells and for accelerating wound healing. J Invest Dermatol. 1999;112(6):866-872.

100. Marx G, Mou X, Hotovely-Salomon A, et al. Heat denaturation of fibrinogen to develop a biomedical matrix. J Biomed Mater Res B Appl Biomater. 2008;84(1):49-57.

101. Rivkin R, Ben-Ari A, Kassis I, et al. High-yield isolation, expansion, and differentiation of murine bone marrow-derived mesenchymal stem cells using fibrin microbeads (FMB). Cloning Stem Cells. 2007;9(2): $157-175$.

102. Ben-Ari A, Rivkin R, Frishman M, Gaberman E, Levdansky L, Gorodetsky R. Isolation and implantation of bone marrow-derived mesenchymal stem cells with fibrin micro beads to repair a critical-size bone defect in mice. Tissue Eng Part A. 2009;15(9):2537-2546.

103. Gorodetsky R, Levdansky L, Gaberman E, Gurevitch O, Lubzens E, McBride WH. Fibrin microbeads loaded with mesenchymal cells support their long-term survival while sealed at room temperature. Tissue Eng Part C Methods. 2011;17(7):745-755.

104. Perka C, Schultz O, Spitzer R-S, Lindenhayn K, Burmester G-R, Sittinger M. Segmental bone repair by tissue-engineered periosteal cell transplants with bioresorbable fleece and fibrin scaffolds in rabbits. Biomaterials. 2000;21(11):1145-1153.

105. Perka C, Arnold U, Spitzer R-S, Lindenhayn K. The use of fibrin beads for tissue engineering and subsequential transplantation. Tissue Eng. 2001;7(3):359-361.

106. Spitzer RS, Perka C, Lindenhayn K, Zippel H. Matrix engineering for osteogenic differentiation of rabbit periosteal cells using $\alpha$-tricalcium phosphate particles in a three-dimensional fibrin culture. $J$ Biomed Mater Res. 2002;59(4):690-696.

107. Zhou H, Chen W, Weir MD, Xu HH. Biofunctionalized calcium phosphate cement to enhance the attachment and osteodifferentiation of stem cells released from fast-degradable alginate-fibrin microbeads. Tissue Eng Part A. 2012;18(15-16):1583-1595.

108. Chen W, Zhou H, Tang M, Weir MD, Bao C, Xu HH. Gas-foaming calcium phosphate cement scaffold encapsulating human umbilical cord stem cells. Tissue Eng Part A. 2011;18(7-8):816-827.

109. Chen W, Zhou H, Weir MD, Bao C, Xu HH. Umbilical cord stem cells released from alginate-fibrin microbeads inside macroporous and biofunctionalized calcium phosphate cement for bone regeneration. Acta Biomater. 2012;8(6):2297-2306.

110. Zhu H, Schulz J, Schliephake H. Human bone marrow stroma stem cell distribution in calcium carbonate scaffolds using two different seeding methods. Clin Oral Implants Res. 2010;21(2):182-188.

111. Lohse N, Schulz J, Schliephake H. Effect of fibrin on osteogenic differentiation and VEGF expression of bone marrow stromal cells in mineralised scaffolds: a three-dimensional analysis. Eur Cell Mater. 2012;23:423-424.

112. Koob S, Torio-Padron N, Stark GB, Hannig C, Stankovic Z, Finkenzeller G. Bone formation and neovascularization mediated by mesenchymal stem cells and endothelial cells in critical-sized calvarial defects. Tissue Eng Part A. 2010;17(3-4):311-321.

113. Nair MB, Varma H, John A. Platelet-rich plasma and fibrin gluecoated bioactive ceramics enhance growth and differentiation of goat bone marrow-derived stem cells. Tissue Eng Part A. 2008;15(7): 1619-1631.

114. Kalia P, Blunn GW, Miller J, Bhalla A, Wiseman M, Coathup MJ. Do autologous mesenchymal stem cells augment bone growth and contact to massive bone tumor implants? Tissue Eng. 2006;12(6):1617-1626.

115. Kopf BS, Schipanski A, Rottmar M, Berner S, Maniura-Weber K. Enhanced differentiation of human osteoblasts on Ti surfaces pretreated with human whole blood. Acta Biomater. 2015;19:180-190.

116. Schantz J-T, Teoh SH, Lim TC, Endres M, Lam CXF, Hutmacher DW. Repair of calvarial defects with customized tissue-engineered bone grafts I. Evaluation of osteogenesis in a three-dimensional culture system. Tissue Eng. 2003;9(4 Suppl 1):113-126. 
117. Schantz J-T, Hutmacher DW, Lam CXF, et al. Repair of calvarial defects with customised tissue-engineered bone grafts II. Evaluation of cellular efficiency and efficacy in vivo. Tissue Eng. 2003;9(4 Suppl 1): 127-139.

118. Hu T, Abbah SA, Toh SY, et al. Bone marrow-derived mesenchymal stem cells assembled with low-dose BMP-2 in a three-dimensional hybrid construct enhances posterolateral spinal fusion in syngeneic rats. Spine J. 2015;15(12):2552-2563.

119. Siddiqui N, Pramanik K. Development of fibrin conjugated chitosan/ nano $\beta$-TCP composite scaffolds with improved cell supportive property for bone tissue regeneration. J Appl Polym Sci. 2015;132(9).

120. Schek RM, Wilke EN, Hollister SJ, Krebsbach PH. Combined use of designed scaffolds and adenoviral gene therapy for skeletal tissue engineering. Biomaterials. 2006;27(7):1160-1166.

121. Yuan X, Smith RJ, Guan H, et al. Hybrid biomaterial with conjugated growth factors and mesenchymal stem cells for ectopic bone formation. Tissue Eng. 2016;22(13-14):928-939.

122. Tayapongsak P, O’Brien DA, Monteiro CB, Arceo-Diaz LY. Autologous fibrin adhesive in mandibular reconstruction with particulate cancellous bone and marrow. J Oral Maxillofac Surg. 1994;52(2): $161-165$.

123. Kim JT, Lee S-H. Reconstruction of inferior orbital wall fractures using bone fragments. J Craniofac Surg. 2015;26(8):2412-2414.

124. Giannini G, Mauro V, Agostino T, Gianfranco B. Use of autologous fibrin-platelet glue and bone fragments in maxillofacial surgery. Transfus Apher Sci. 2004;30(2):139-144.

125. Segura-Castillo JL, Aguirre-Camacho H, González-Ojeda A, MichelPerez J. Reduction of bone resorption by the application of fibrin glue in the reconstruction of the alveolar cleft. J Craniofac Surg. 2005; 16(1):105-112.

126. Huh J-Y, Choi B-H, Zhu S-J, Jung J-H, Kim B-Y, Lee S-H. The effect of platelet-enriched fibrin glue on bone regeneration in autogenous bone grafts. Oral Surg Oral Med Oral Pathol Oral Radiol Endod. 2006;101(4):426-431.

127. Lee H-J, Choi B-H, Jung J-H, et al. Vertical alveolar ridge augmentation using autogenous bone grafts and platelet-enriched fibrin glue with simultaneous implant placement. Oral Surg Oral Med Oral Pathol Oral Radiol Endod. 2008;105(1):27-31.

128. Lee H-J, Choi B-H, Jung J-H, et al. Maxillary sinus floor augmentation using autogenous bone grafts and platelet-enriched fibrin glue with simultaneous implant placement. Oral Surg Oral Med Oral Pathol Oral Radiol Endod. 2007;103(3):329-333.

129. Hallman M, Cederlund A, Lindskog S, Lundgren S, Sennerby L. A clinical histologic study of bovine hydroxyapatite in combination with autogenous bone and fibrin glue for maxillary sinus floor augmentation. Clin Oral Implants Res. 2001;12(2):135-143.

130. Hallman M, Lundgren S, Sennerby L. Histologic analysis of clinical biopsies taken 6 months and 3 years after maxillary sinus floor augmentation with $80 \%$ bovine hydroxyapatite and $20 \%$ autogenous bone mixed with fibrin glue. Clin Implant Dent Relat Res. 2001;3(2): $87-96$.

131. Hallman M, Zetterqvist L. A 5-Year Prospective Follow-Up Study of Implant-Supported Fixed Prostheses in Patients Subjected to Maxillary Sinus Floor Augmentation with an 80:20 Mixture of Bovine Hydroxyapatite and Autogenous Bone. Clin Implant Dent Relat Res. 2004;6(2):82-89.

132. Le Guéhennec L, Layrolle P, Daculsi G. A review of bioceramics and fibrin sealant. Eur Cell Mater. 2004;8(13):1e11.

133. Woo KM, Yu B, Jung HM, Lee YK. Comparative evaluation of different crystal-structured calcium sulfates as bone-filling materials. J Biomed Mater Res B Appl Biomater. 2009;91(2):545-554.

134. Dong J, Cui G, Bi L, Li J, Lei W. The mechanical and biological studies of calcium phosphate cement-fibrin glue for bone reconstruction of rabbit femoral defects. Int J Nanomedicine. 2013;8:1317-1324.

135. Cui G, Li J, Lei W, et al. The mechanical and biological properties of an injectable calcium phosphate cement-fibrin glue composite for bone regeneration. J Biomed Mater Res B Appl Biomater. 2010; 92(2):377-385.
136. Kania R, Meunier A, Hamadouche M, Sedel L, Petite H. Addition of fibrin sealant to ceramic promotes bone repair: long-term study in rabbit femoral defect model. J Biomed Mater Res. 1998;43(1):38-45.

137. Qian G, Dong Y, Yang W, Wang M. Injectable calcium phosphate cement and fibrin sealant recombined human bone morphogenetic protein-2 composite in vertebroplasty: an animal study. Bosn J Basic Med Sci. 2012;12(4):231-235.

138. Le Guehennec L, Goyenvalle E, Aguado E, et al. $\mathrm{MBCP}^{\circledR}$ biphasic calcium phosphate granules and tissucol ${ }^{\circledR}$ fibrin sealant in rabbit femoral defects: the effect of fibrin on bone ingrowth. J Mater Sci Mater Med. 2005;16(1):29-35.

139. Saffarzadeh A, Gauthier O, Bilban M, Bagot D’Arc M, Daculsi G. Comparison of two bone substitute biomaterials consisting of a mixture of fibrin sealant $\left(\right.$ Tisseel $\left.^{\circledR}\right)$ and $\mathrm{MBCP}{ }^{\mathrm{TM}}\left(\right.$ TricOs $\left.^{\circledR}\right)$ with an autograft in sinus lift surgery in sheep. Clin Oral Implants Res. 2009;20(10): $1133-1139$.

140. Reppenhagen S, Reichert JC, Rackwitz L, et al. Biphasic bone substitute and fibrin sealant for treatment of benign bone tumours and tumour-like lesions. Int Orthop. 2012;36(1):139-148.

141. van Esterik FA, Zandieh-Doulabi B, Kleverlaan CJ, Klein-Nulend J. Enhanced osteogenic and vasculogenic differentiation potential of human adipose stem cells on biphasic calcium phosphate scaffolds in fibrin gels. Stem Cells Int. 2016;2016:1934270.

142. Carmagnola D, Berglundh T, Lindhe J. The effect of a fibrin glue on the integration of Bio-Oss ${ }^{\circledR}$ with bone tissue. J Clin Periodontol. 2002;29(5):377-383.

143. Pinholt EM, Solheim E, Bang G, Sudmann E. Bone induction by composites of bioresorbable carriers and demineralized bone in rats: a comparative study of fibrin-collagen paste, fibrin sealant, and polyorthoester with gentamicin. J Oral Maxillofac Surg. 1992;50(12):1300-1304.

144. Bösch P, Braun F, Eschberger J, Kovac W, Spängler H. Die Beeinflussung der Knochenheilung durch hochkonzentriertes Fibrin. [The action of high-concentrated fibria on bone healing (author's transl)]. Arch Orthop Unfallchir. 1977;89(3):259-273. German.

145. Arnaud E, Morieux C, Wybier M, De Vernejoul M. Potentiation of transforming growth factor (TGF- $\beta 1$ ) by natural coral and fibrin in a rabbit cranioplasty model. Calcified Tissue Int. 1994;54(6):493-498.

146. Schek RM, Hollister SJ, Krebsbach PH. Delivery and protection of adenoviruses using biocompatible hydrogels for localized gene therapy. Mol Ther. 2004;9(1):130-138.

147. Seebach E, Freischmidt H, Holschbach J, Fellenberg J, Richter W. Mesenchymal stroma cells trigger early attraction of M1 macrophages and endothelial cells into fibrin hydrogels, stimulating long bone healing without long-term engraftment. Acta Biomater. 2014;10(11): 4730-4741.

148. Kim S-J, Jang J-D, Lee S-K. Treatment of long tubular bone defect of rabbit using autologous cultured osteoblasts mixed with fibrin. Cytotechnology. 2007;54(2):115-120.

149. Zhu S-J, Choi B-H, Huh J-Y, Jung J-H, Kim B-Y, Lee S-H. A comparative qualitative histological analysis of tissue-engineered bone using bone marrow mesenchymal stem cells, alveolar bone cells, and periosteal cells. Oral Surg Oral Med Oral Pathol Oral Radiol Endod. 2006;101(2):164-169.

150. Zhao H, Ma L, Gao C, Wang J, Shen J. Fabrication and properties of injectable $\beta$-tricalcium phosphate particles/fibrin gel composite scaffolds for bone tissue engineering. Mater Sci Eng C. 2009;29(3):836-842.

151. Khojasteh A, Eslaminejad MB, Nazarian H, et al. Vertical bone augmentation with simultaneous implant placement using particulate mineralized bone and mesenchymal stem cells: a preliminary study in rabbit. J Oral Implantol. 2013;39(1):3-13.

152. Ito K, Yamada Y, Naiki T, Ueda M. Simultaneous implant placement and bone regeneration around dental implants using tissue-engineered bone with fibrin glue, mesenchymal stem cells and platelet-rich plasma. Clin Oral Implants Res. 2006;17(5):579-586.

153. Liu Z, Zhu Y, Zhu H, He X, Liu X. Enhancement of posterolateral lumbar spine fusion using recombinant human bone morphogenetic protein-2 and mesenchymal stem cells delivered in fibrin glue. J Biomater Appl. 2016;31(4):477-487. 
154. Mehrkens A, Saxer F, Guven S, et al. Intraoperative engineering of osteogenic grafts combining freshly harvested, human adipose-derived cells and physiological doses of bone morphogenetic protein-2. Eur Cell Mater. 2012;24:308-319.

155. Müller A, Mehrkens A, Schäfer D, et al. Towards an intraoperative engineering of osteogenic and vasculogenic grafts from the stromal vascular fraction of human adipose tissue. Eur Cell Mater. 2010;19: 127-135.

156. Saxer F, Scherberich A, Todorov A, et al. Implantation of stromal vascular fraction progenitors at bone fracture sites: from a rat model to a first-in-man study. Stem Cells. 2016;34(12):2956-2966.

157. Schützenberger S, Schultz A, Hausner T, et al. The optimal carrier for BMP-2: a comparison of collagen versus fibrin matrix. Arch Orthop Traum Su. 2012;132(9):1363-1370.

158. Schmoekel H, Schense JC, Weber FE, et al. Bone healing in the rat and dog with nonglycosylated BMP-2 demonstrating low solubility in fibrin matrices. J Orthop Res. 2004;22(2):376-381.

159. Hong S-J, Kim C-S, Han D-K, et al. The effect of a fibrinfibronectin/ $\beta$-tricalcium phosphate/recombinant human bone morphogenetic protein-2 system on bone formation in rat calvarial defects. Biomaterials. 2006;27(20):3810-3816.

160. Patel VV, Zhao L, Wong P, et al. An in vitro and in vivo analysis of fibrin glue use to control bone morphogenetic protein diffusion and bone morphogenetic protein-stimulated bone growth. Spine J. 2006; 6(4):397-403.

161. Schmoekel H, Weber F, Hurter K, et al. Enhancement of bone healing using non-glycosylated rhBMP-2 released from a fibrin matrix in dogs and cats. J Small Anim Pract. 2005;46(1):17-21.

162. Schmoekel HG, Weber FE, Schense JC, Grätz KW, Schawalder P, Hubbell JA. Bone repair with a form of BMP-2 engineered for incorporation into fibrin cell ingrowth matrices. Biotechnol Bioeng. 2005; 89(3):253-262.

163. Yang HS, La W-G, Bhang SH, Jeon J-Y, Lee JH, Kim B-S. Heparinconjugated fibrin as an injectable system for sustained delivery of bone morphogenetic protein-2. Tissue Eng Part A. 2010;16(4): 1225-1233.

164. Yang HS, La W-G, Bhang SH, et al. Hyaline cartilage regeneration by combined therapy of microfracture and long-term bone morphogenetic protein-2 delivery. Tissue Eng Part A. 2011;17(13-14):1809-1818.

165. La WG, Kwon SH, Lee TJ, Yang HS, Park J, Kim BS. The effect of the delivery carrier on the quality of bone formed via bone morphogenetic protein-2. Artif Organs. 2012;36(7):642-647.

166. Hong J-Y, Kang S-W, Kim J-W, Suh S-W, Ko Y-J, Park J-H. Optimal condition of heparin-conjugated fibrin with bone morphogenetic protein-2 for spinal fusion in a rabbit model. Cytotherapy. 2014;16(10): 1441-1448.

167. Lee JS, Lee SK, Kim BS, Im GI, Cho KS, Kim CS. Controlled release of BMP-2 using a heparin-conjugated carrier system reduces in vivo adipose tissue formation. J Biomed Mater Res A. 2015;103(2): $545-554$.

168. Jeon O, Song SJ, Yang HS, et al. Long-term delivery enhances in vivo osteogenic efficacy of bone morphogenetic protein-2 compared to short-term delivery. Biochem Biophys Res Commun. 2008;369(2): 774-780

169. Kim SS, Gwak SJ, Kim BS. Orthotopic bone formation by implantation of apatite-coated poly (lactide-co-glycolide)/hydroxyapatite composite particulates and bone morphogenetic protein-2. J Biomed Mater Res A. 2008;87(1):245-253.

170. Noh S-S, Bhang SH, La W-G, et al. A dual delivery of substance $\mathrm{P}$ and bone morphogenetic protein-2 for mesenchymal stem cell recruitment and bone regeneration. Tissue Eng Part A. 2015;21(7-8): 1275-1287.

171. Usas A, Ho AM, Cooper GM, Olshanski A, Peng H, Huard J. Bone regeneration mediated by BMP4-expressing muscle-derived stem cells is affected by delivery system. Tissue Eng Part A. 2008;15(2): 285-293.
172. Sheyn D, Kallai I, Tawackoli W, et al. Gene-modified adult stem cells regenerate vertebral bone defect in a rat model. Mol Pharm. 2011; 8(5):1592-1601.

173. Pelled G, Sheyn D, Tawackoli W, et al. BMP6-engineered MSCs induce vertebral bone repair in a pig model: a pilot study. Stem Cells Int. 2016;2016:6530624.

174. Mizrahi O, Sheyn D, Tawackoli W, et al. BMP-6 is more efficient in bone formation than BMP-2 when overexpressed in mesenchymal stem cells. Gene Ther. 2013;20(4):370-377.

175. Tabata Y, Yamada K, Miyamoto S, et al. Bone regeneration by basic fibroblast growth factor complexed with biodegradable hydrogels. Biomaterials. 1998;19(7):807-815.

176. Jeon O, Ryu SH, Chung JH, Kim B-S. Control of basic fibroblast growth factor release from fibrin gel with heparin and concentrations of fibrinogen and thrombin. J Control Release. 2005;105(3): 249-259.

177. Vila OF, Martino MM, Nebuloni L, et al. Bioluminescent and microcomputed tomography imaging of bone repair induced by fibrinbinding growth factors. Acta Biomater. 2014;10(10):4377-4389.

178. Arrighi I, Mark S, Alvisi M, von Rechenberg B, Hubbell JA, Schense JC. Bone healing induced by local delivery of an engineered parathyroid hormone prodrug. Biomaterials. 2009;30(9):1763-1771.

179. Jing D, Hao X, Xu F, et al. Effects of local delivery of BMP2, zoledronate and their combination on bone microarchitecture, biomechanics and bone turnover in osteoporotic rabbits. Sci Rep. 2016;6: 28537.

180. Woodruff MA, Rath SN, Susanto E, et al. Sustained release and osteogenic potential of heparan sulfate-doped fibrin glue scaffolds within a rat cranial model. J Mol Histol. 2007;38(5):425-433.

181. Tofuku K, Koga H, Yanase M, Komiya S. The use of antibioticimpregnated fibrin sealant for the prevention of surgical site infection associated with spinal instrumentation. Eur Spine J. 2012;21(10): 2027-2033.

182. Hou T, Xu J, Li Q, Feng J, Zen L. In vitro evaluation of a fibrin gel antibiotic delivery system containing mesenchymal stem cells and vancomycin alginate beads for treating bone infections and facilitating bone formation. Tissue Eng Part A. 2008;14(7):1173-1182.

183. Chang Z, Hou T, Wu X, et al. An anti-infection tissue-engineered construct delivering vancomycin: its evaluation in a goat model of femur defect. Int J Med Sci. 2013;10(12):1761-1770.

184. Xing J, Hou T, Luobu B, et al. Anti-infection tissue engineering construct treating osteomyelitis in rabbit tibia. Tissue Eng Part A. 2012; 19(1-2):255-263.

185. Linnes MP, Ratner BD, Giachelli CM. A fibrinogen-based precision microporous scaffold for tissue engineering. Biomaterials. 2007; 28(35):5298-5306.

186. Osathanon T, Linnes ML, Rajachar RM, Ratner BD, Somerman MJ, Giachelli CM. Microporous nanofibrous fibrin-based scaffolds for bone tissue engineering. Biomaterials. 2008;29(30):4091-4099.

187. Osathanon T, Giachelli CM, Somerman MJ. Immobilization of alkaline phosphatase on microporous nanofibrous fibrin scaffolds for bone tissue engineering. Biomaterials. 2009;30(27):4513-4521.

188. Perumcherry SR, Chennazhi KP, Nair SV, Menon D, Afeesh R. A novel method for the fabrication of fibrin-based electrospun nanofibrous scaffold for tissue-engineering applications. Tissue Eng Part C Methods. 2011;17(11):1121-1130.

189. Sreerekha PR, Menon D, Nair SV, Chennazhi KP. Fabrication of electrospun poly (lactide-co-glycolide)-fibrin multiscale scaffold for myocardial regeneration in vitro. Tissue Eng Part A. 2012;19(7-8): 849-859.

190. Praveen G, Sreerekha P, Menon D, Nair SV, Chennazhi KP. Fibrin nanoconstructs: a novel processing method and their use as controlled delivery agents. Nanotechnology. 2012;23(9):095102.

191. Priya MV, Sivshanmugam A, Boccaccini A, et al. Injectable osteogenic and angiogenic nanocomposite hydrogels for irregular bone defects. Biomed Mater. 2016;11(3):035017. 
192. Kumar RA, Sivashanmugam A, Deepthi S, Bumgardner JD, Nair SV, Jayakumar R. Nano-fibrin stabilized $\mathrm{CaSO}_{4}$ crystals incorporated injectable chitin composite hydrogel for enhanced angiogenesis \& osteogenesis. Carbohydr Polym. 2016;140:144-153.

193. Vedakumari WS, Prabu P, Babu SC, Sastry TP. Fibrin nanoparticles as possible vehicles for drug delivery. Biochim Biophys Acta. 2013; 1830(8):4244-4253.

194. Periyathambi P, Vedakumari WS, Baskar SK, Bojja S, Sastry TP. Osteogenic potency of magnetic fibrin nanoparticles - a novel perspective in bone tissue engineering. Mater Lett. 2015;139:108-111.

195. Vedakumari WS, Priya VM, Sastry TP. Deposition of superparamagnetic nanohydroxyapatite on iron-fibrin substrates: preparation, characterization, cytocompatibility and bioactivity studies. Colloids Surf B Biointerfaces. 2014;120:208-214.

196. Dolder JVD, Mooren R, Vloon AP, Stoelinga PJ, Jansen JA. Plateletrich plasma: quantification of growth factor levels and the effect on growth and differentiation of rat bone marrow cells. Tissue Eng. 2006; 12(11):3067-3073.
197. Yamada Y, Boo JS, Ozawa R, et al. Bone regeneration following injection of mesenchymal stem cells and fibrin glue with a biodegradable scaffold. J Craniomaxillofac Surg. 2003;31(1):27-33.

198. Davis HE, Binder BY, Schaecher P, Yakoobinsky DD, Bhat A, Leach JK. Enhancing osteoconductivity of fibrin gels with apatite-coated polymer microspheres. Tissue Eng Part A. 2013;19(15-16):1773-1782.

199. Zhu S-J, Choi B-H, Jung J-H, et al. A comparative histologic analysis of tissue-engineered bone using platelet-rich plasma and plateletenriched fibrin glue. Oral Surg Oral Med Oral Pathol Oral Radiol Endod. 2006;102(2):175-179.

200. Murphy KC, Stilhano RS, Mitra D, et al. Hydrogel biophysical properties instruct coculture-mediated osteogenic potential. FASEB $J$ 2016;30(1):477-486.
International Journal of Nanomedicine

\section{Publish your work in this journal}

The International Journal of Nanomedicine is an international, peerreviewed journal focusing on the application of nanotechnology in diagnostics, therapeutics, and drug delivery systems throughout the biomedical field. This journal is indexed on PubMed Central, MedLine, CAS, SciSearch ${ }^{\circledR}$, Current Contents ${ }^{\circledR} /$ Clinical Medicine,

\section{Dovepress}

Journal Citation Reports/Science Edition, EMBase, Scopus and the Elsevier Bibliographic databases. The manuscript management system is completely online and includes a very quick and fair peer-review system, which is all easy to use. Visit http://www.dovepress.com/ testimonials.php to read real quotes from published authors.

Submit your manuscript here: http://www.dovepress.com/international-journal-of-nanomedicine-journal 